\title{
STIRNER: DA NADIFICAÇão AO MOMENTO ÉtiCo DA INTIMIDADE PROPRIETÁRIA
}

\author{
José Barata-Moura
}

(Universidade de Lisboa)

\section{§ 1. Uma teoria metafísica da nadificação}

Encarado por um determinado ângulo de formalidade, Der Einzige und sein Eigentum de Max Stirner - publicado, em Leipzig, por Otto Wigand com data de 1845, mas com uma tiragem começada a distribuir, com forte probabilidade, em Outubro de $1844^{1}$-, desdobra-nos, aparentemente, uma teoria metafísica da nadificação.

$\mathrm{Na}$ verdade, e como é sobejamente conhecido, a declaração sonante com que se inaugura, e por que se conclui, esta obra reza: «Ich hab" mein' Sach' auf Nichts gestellt» ${ }^{2}-$ o que, sem traduzir na sua plenitude os matizes idiomáticos de que se reveste, e a paleta de alusões intertextuais para que remete ${ }^{3}$, se poderia verter por «coloquei a minha causa em

${ }^{1}$ Veja-se a nota de Wolfgang MÖNKE, em Moses HESS, Philosophische und Sozialistische Schriften, 1837-1850. Eine Auswahl, ed. W. Mönke (doravante: PSS), Berlin, Akademie-Verlag, $1980^{2}$, pp. 498-499, onde igualmente se dá conta das vicissitudes que rodearam os diferentes procedimentos censórios de que a obra começou por ser objecto na Saxónia e na Prússia.

${ }^{2}$ Cf. Max STIRNER, Der Einzige und sein Eigentum, ed. Ahlrich Meyer, Suttgart, Philipp Reclam jun., $1981^{2}$, respectivamente, pp. 3 e 412.

${ }^{3}$ Afigura-se-me que, designadamente, seria de ter em conta aqui uma conhecida chanson à boire de Goethe. Glosando, não sem irreverências várias, um tema bíblico (cf. Eclesiastes, 1, 2 ess.), o poema é construído sobre as diferentes «causas» a que se vai entregando a vida, e também ele começa - e, praticamente, acaba - com a expressão: «Ich hab' mein Sach' auf Nichts gestellt», depreendendo-se da tomada dessa atitude tanto uma pacificação no relacionamento com o mundo, como uma sua apropriação. Cf. Johann Wolfgang von GOETHE, «Vanitas! Vanitatum vanitas!» (1806), Geselliger Lieder (1815); Werke. Weimarer Ausgabe, ed. Sophie von Sachsen (doravante: WW), reprod. München, Deutscher Taschenbuch Verlag, 1987, vol. 1, pp. 132-133.

Philosophica, 41, Lisboa, 2013, pp. 7-56 
nada», «assentei em nada a minha causa», ou, numa acepção até certo ponto mais livre (embora justificada): «fiz do nada a minha causa» ${ }^{4}$.

Em termos genéricos, com efeito, quando se pretende instaurar o pensar, e com ele a filosofia, a partir de uma ausência absoluta de pressupostos, é expectável que - de radicalizações em radicalismos escavando se acabe por começar por coisa nenhuma.

Não foi certamente por acaso que Johann Gottlieb Fichte cuidou, a dada altura da reconfiguração da sua Wissenschaftslehre, de estabelecer a equação: "Idealismus = Nihilismus", , entendendo por tal "nihilismo", principialmente, o "desmoronamento da realidade" (Sturz der Realität) ${ }^{6}$.

Este procedimento carrega, na verdade, consigo uma larga, nutrida, e diversificada tradição.

No fundo, trata-se de explorar doutrinalmente o contrapé do antigo axioma helénico, em que as ressonâncias materialistas são com nitidez audíveis, segundo o qual «nada acontece [devém, ou se engendra] a partir

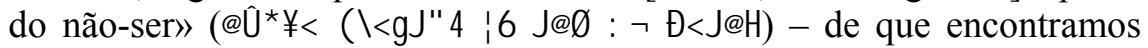
ecos não só em Demócrito ${ }^{7}$ e em Epicuro ${ }^{8}$, mas também em Aristóteles ${ }^{9}$.

Como, aliás, Ludwig Feuerbach - no contexto de uma réplica aos comentários críticos de Max Stirner declinados em Der Einzige und sein

\footnotetext{
${ }^{4}$ No seu dicionário, os irmãos Grimm explicam que a expressão «colocar a sua causa em algo» (seine sache auf etwas stellen) significa: «fazer de algo a base da sua tarefa, da sua obrigação, do seu modo de agir» (etwas zur grundlage seiner aufgabe, seiner pflicht, seiner handlungsweise machen). Cf. Jacob GRIMM e Wilhelm GRIMM, «Sache», Deutsches Wörterbuch (1893), reprod. München, Deutscher Taschenbuch Verlag, 1984, vol. 14, col. 1596.

Por sua vez, no contexto do arranque da obra de Stirner, esta interpretação igualmente me parece defensável, na medida em que se trata aí de, com o «Nada» (Nichts), introduzir uma demarcação relativamente àquilo que, na generalidade dos casos, é entendido como sendo o objecto da «boa causa» (gute Sache): «Deus» (Gott), a «Humanidade» (como Menschheit e como Humanität), a «Justiça» (Gerechtigkeit), a «Verdade» (Wahrheit), a «Pátria» (Vaterland), o «Povo» (Volk), etc. Cf. STIRNER, EE, Ich hab' Mein Sach' auf Nichts gestellt; p. 3.

${ }^{5} \mathrm{Cf}$. Johann Gottlieb FICHTE, Einleitungsvorlesungen in die Wissenschaftslehre (1813); Nachgelassene Werke, ed. Immanuel Hermann Fichte (doravante: SW), reprod. Berlin, Walter de Gruyter \& Co., 1971, vol. IX, p. 39.

${ }^{6}$ Cf. FICHTE, Die Wissenschaftslehre (1812); SW, vol. X, p. 325.

${ }^{7}$ Cf. DEMÓCRITO, Fragmento A 1; Die Fragmente der Vorsokratiker, ed. Hermann Diels e Walther Kranz (doravante: FVS), Berlin, Weidmannsche Verlagsbuchhandlung, $1952^{6}$, vol. II, p. 84.

${ }^{8}$ Cf. EPICURO, Carta a Heródoto, 38; Epistulae tres et ratae sententiae a Laertio Diogene servatae, ed. P. Von der Muehll, Stuttgart, B. G. Teubner, $1975^{3}$, p. 5.

${ }^{9}$ Cf. ARISTÓTELES, Metafísica, K, 6, 1062 b 24-26; e também Física, I, 8, 191 b 13-15.
} 
Eigentum - não deixará de observar, numa nota à segunda edição (1846) do seu escrito: "A proposição "Deus é nada ou [é] o Nada" encontra-se, como é sabido, não apenas em religiões orientais, mas também em místicos e exaltados [visionários, Schwärmer] cristãos.» ${ }^{10}$

No marco do idealismo, em geral, o problema prende-se, de facto, com a necessidade de introduzir uma diferença «ontológica», que permita, de alguma maneira, antepôr à materialidade do ser alguma outra instância subjectiva como sua condição originária de possibilidade. A variação doutrinária nesse âmbito - a par da própria compreensão em concreto de «aquilo que é» - consistirá certamente na identificação da figura, e na determinação do teor, desse «nada» de que o «ser» é dito arrancar.

Por paradoxal que pareça, estamos perante uma problemática metafísica que não era de todo estranha aos interesses especulativos de Max Stirner. Pelo menos, se tomarmos como correcta uma recolecção que Friedrich Engels transmite tardiamente (1889) a um seu correspondente, acerca da convivência mantida com Stirner em Berlin, por 1842, no decorrer das animadas tertúlias em torno do grupo dos Freien ${ }^{11}$ :

10 «Der Satz: "Gott ist nichts oder das Nichts", findet sich bekanntlich nicht nur in orientalischen Religionen, sondern auch bei christlichen Mystikern und Schwärmern.», Ludwig FEUERBACH, Über das "Wesen des Christentums" in Beziehung auf den "Einzigen und sein Eigentum”; Gesammelte Werke, ed. Werner Schuffenhauer (doravante: GW), Berlin, Akademie-Verlag, 1982², vol. 9, p. 428.

11 Veja-se a crónica de Stirner dedicada ao grupo, publicada em Julho de 1842, na Leipziger Allgemeine Zeitung, onde uma franca tonalidade de simpatia prevalece. Cf. STIRNER, Die Freien (1842); Kleinere Schriften, und seine Entgegnungen auf die Kritik seines Werkes: "Der Einzige und sein Eigenthum" aus den Jahren 1842-1848, ed. John Henry Mackay (doravante: KS), reprod. da $2^{\mathrm{a}}$ edição (1914): Stuttgart - Bad Cannstatt, Frommann Verlag - Günther Holzboog, 1976, pp. 132$-141$.

Escasso tempo volvido, pelo contrário, a expressão «Die Freien» aparecerá como a designação genérica das diferentes variedades de «liberalismo» coevo que serão objecto central de crítica. Cf. STIRNER, EE, 1, II, 3; pp. 106-167.

$\mathrm{Na}$ descrição bem-humorada, a que não falta o calor da cumplicidade, de alguns dos membros do círculo dos Freien - publicada num folheto de 1842 (redigido em colaboração com Edgar Bauer) -, Engels caracteriza Stirner como um espírito «compassado que odeia limitações» (bedächtiger Schrankenhasser) que, tomando cerveja enquanto não pode beber «sangue como água» (Blut wie Wasser), vai verberando a «escravatura» (Sclaverei) em que generalizadamente se vegeta e prodigalizando os seus libertadores gritos de «fora o estatuto [ou a norma], fora a lei!» (weg Satzung, weg Gesetz!). Cf. Friedrich ENGELS, Die frech bedräute, jedoch wunderbar befreite Bibel. Oder: Der Triumph des Glaubens (1842); Marx - Engels Gesamtausgabe, ed. Günter Heyden e Anatoli Jegorow (doravante: MEGA2 ), Berlin, Dietz Verlag, 1985, vol. I/3, respectivamente, pp. 407 e 411.

Como é sabido, Marx, contrariamente ao jovem Engels (no seu percurso berlinense destes anos), nunca foi apreciador das tiradas altissonantes dos Freien, amiúde 
Nós discutíamos muito acerca de filosofia hegeliana; ele tinha feito nessa altura a descoberta de que a Lógica de Hegel começa por um erro: o ser, que se manifesta como o nada e assim entra em oposição consigo próprio, não pode ser o começo; o começo tem que ser feito com algo que é ele próprio já a unidade imediata, naturalmente dada, de ser e nada, e a partir do qual somente esta oposição se desenvolve. E isto era, segundo Stirner, o "Es" [a forma impessoal neutra que se subentende em] (neva, chove [es schneit, es regnet]), algo que é e, simultaneamente, também é nada. Posteriormente, parece contudo então que ele percebeu [dahinterkommen] que com o "Es", não menos do que com o ser e nada, não acontece todavia nada [ou não se vai a parte nenhuma, doch nichts ist $]^{12}$.

Na verdade, para Hegel, o «ser» (Sein) que no começo da Wissenschaft der Logik se insinua - pela pureza completa da sua «falta de determinação» (Bestimmungslosigkeit) - identifica-se com o «nada» (Nichts): «O ser, o imediato indeterminado, é de facto nada, e nem mais nem menos do que nada.» ${ }^{13}$

No entanto, esta tese hegeliana que visa dar conta de um começo onde a unidade de «ser»e «nada» se firma e desenvolve no e pelo «devir» (Werden), que os enlaça e lhes proporciona determinação, não revela por inteiro o segredo metafísico do «haver ser», posto que não despede a

classificadas como «borradas prenhes de revolucionamento mundial e vazias de pensamento, em estilo porco, misturadas com algo de ateísmo e de comunismo (que os senhores nunca estudaram)» - «Weltumwälzungsschwangre und Gedankenleere Sudeleien in saloppen Styl, mit etwas Atheismus und Communismus (den die Herrn nie studiert haben)», Karl MARX, Brief an Arnold Ruge, 30. November 1842; $\mathrm{MEGA}^{2}$, vol. III/1, p. 37.

12 «Wir diskutierten viel über Hegelsche Philosophie, er hatte damals die Entdeckung gemacht, daß Hegels Logik mit einem Fehler anfängt: Das Sein, welches sich als das Nichts erweist und so in Gegensatz mit sich selbst tritt, kann nicht der Anfang sein; der Anfang muß gemacht werden mit etwas, das selbst schon die unmittelbare, naturwüchsig gegebne Einheit von Sein und Nichts ist und aus dem erst dieser Gegensatz sich entwickelt. Und dies war nach Stirner das "Es" (es schneit, es regnet), etwas das ist und zugleich auch Nichts ist. Nachher scheint er dann doch dahintergekommen zu sein, daß es mit dem Es, nicht minder als mit dem Sein und Nichts, doch nichts ist.», ENGELS, Brief an Max Hildebrand, 22. Oktober 1889; Marx - Engels Werke, ed. IML (doravante: MEW), Berlin, Dietz Verlag, 1974, vol. 37, pp. 292-293.

13 «Das Sein, das unbestimmte Unmittelbare ist in der Tat Nichts und nicht mehr noch weniger als Nichts.», Georg Wilhelm Friedrich HEGEL, Wissenschaft der Logik, I, I, I, 1, A; Theorie Werkausgabe, red. Eva Moldenhauer e Karl Markus Michel (doravante: TW), Frankfurt am Main, Suhrkamp Verlag, 1969, vol. 5, p. 83 . 
necessidade de uma instância que tudo suporta, e em que tudo se vem a resolver. A instância fundante, para Hegel, não será esse «Es» de que Stirner teria em algum momento falado, mas é o «Espírito», o Geist, que na sua absolutidade constitui, de facto, «o idealista propriamente dito, em geral» (der eigentliche Idealist überhaupt $)^{14}$.

A solução concepcionalmente encontrada por Hegel para resolver e compatibilizar a «idealidade» e a «objectividade» - no fim das contas, o tributo que Hegel tem que pagar ao idealismo para assentar uma dialecticidade do real, em que a finitude positivada não é reconhecida verdadeiramente como «ente», ou «como algo que verdadeiramente é» (als ein wahrhaft Seiendes) ${ }^{15}$ - não se apresenta todavia, para Stirner, como satisfatória. Desde logo, por duas ordens convergentes de razões.

Por um lado, porque, do ponto de vista metafísico, a singularidade coisal não pode deixar de ser preservada na sua onticidade, já que toda a universalidade se apresenta como de natureza «fantasmática»: «Um objecto [Gegenstand] elevado acima da singularidade das coisas é a essência [Wesen] das coisas; sim, a essência é somente o pensável [das Denkbare] nelas, é», simplesmente, «para o ser humano que pensa.» ${ }^{16}$.

Por outro lado, porque o expediente hegeliano da radicação - a dissolução de tudo «aquilo que é» em «pensamento» (Gedanken) de um «pensar» (Denken) de que, em última instância, o «Espírito» (Geist) se constitui como «sujeito» - a continua dependente, perspectivado da posição de uma individualidade que pensa, de uma fundamental e estruturante figura da «alienação».

E vemo-nos, assim, regressados aqui de novo à questão inicial dos «pressupostos». A questão é, na verdade, importante, porque coloca o problema inaugurante do «haver ser», e, na dinâmica da concepção de Stirner, vai obrigar à rejeição de que tanto ao «pensar» (Denken), como a «um pensado» (ein Gedachtes), seja conferido o estatuto (último, ou primeiro) de fundamento.

«Pressupôr» - escreve Stirner, num contexto em que se encontram visados, fundamentalmente, tanto o «sistema» de Hegel, em geral, quanto a «Crítica» entronizada pelos irmãos Bauer - «não significa senão colo-

${ }^{14}$ Cf. HEGEL, Wissenschaft der Logik, I, I, I, 2, Anmerkung 2; TW, vol. 5, p. 173.

15 «O idealismo da filosofia não consiste em outra coisa senão nisto: não reconhecer o finito como um ente verdadeiro.» - «Der Idealismus der Philosophie besteht in nichts anderem als darin, das Endliche nicht als ein wahrhaft Seiendes anzuerkennen.», HEGEL, Wissenschaft der Logik, I, I, I, 2, Anmerkung 2; TW, vol. 5, p. 172.

16 «Ein über die Einzelheit der Dinge erhabener Gegenstand ist das Wesen der Dinge; ja das Wesen ist allein das Denkbare an ihnen, ist für den denkenden Menschen.», STIRNER, EE, 2, II, 3; p. 375. 
car à frente [voranstellen] um pensamento [Gedanken], ou pensar algo antes de tudo o mais e, a partir desse pensado [Gedachtes], pensar o restante, isto é, medir e criticar por ele. Por outras palavras, isso diz que o pensar deve principiar por um pensado. Se o pensar, em geral, principiasse, em vez de ser principiado, se o pensar [Denken] fosse um sujeito, uma personalidade própria agente, como já a planta o é, decerto que não seria de prescindir de que o pensar tenha que começar consigo [mesmo].»1 ${ }^{17}$

Simplesmente, esta «personificação do pensar» (Personifikation des Denkens) acarreta, aos olhos de Stirner, inúmeros erros de perspectiva e de fundamentação.

A hipostasiação de uma ordem (abstracta) de pensamento como uma entidade «outra» representa aqui, por conseguinte, um desapossamento inaugural de uma dimensão que é «própria» (do indivíduo que pensa), e uma subordinação desmedida deste a algo de alheio (que por inteiro lhe escapa): «O pensar, porém, como [algo de] pressuposto [Voraus-

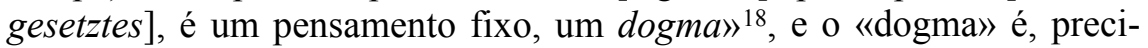
samente, tudo aquilo que se firma e afirma - como já Kant insistira ${ }^{19}$, e Fichte havia tratado de reconfigurar na sua doutrina do $\langle\mathrm{Eu}\rangle^{20}-$ num tabuleiro que radicalmente exclui o exame crítico por parte do pensante, ou atenta contra a singular originariedade fontal do seu estatuto.

Se estamos a falar de pressupostos - e a falar de pressupostos dentro de uma moldura idealista, acrescento eu, uma vez que todas as questões da fundamentação material da própria ordem da subjectividade se encontram aqui, higienicamente, por completo arredadas da consideração -,

17 «Voraussetzen heißt nichts anders, als einen Gedanken voranstellen, oder etwas vor allem Andern denken und von diesem Gedachten aus das Übrige denken, d. h. es daran messen und kritisieren. Mit andern Worten sagt dies so viel, daß das Denken mit einem Gedachten beginnen soll. Begönne das Denken überhaupt, statt begonnen zu werden, wäre das Denken ein Subjekt, eine eigene handelnde Persönlichkeit, wie schon die Pflanze eine solche ist, so wäre freilich nicht davon abzustehen, daß das Denken mit sich anfangen müsse.», STIRNER, EE, 2, II, 3; p. 394.

18 «Das Denken aber, als Vorausgesetztes, ist ein fixer Gedanke, ein Dogma», STIRNER, EE, 2, II, 3; p. 395.

19 «O procedimento dogmático da razão pura» (das dogmatische Verfahren der reinen Vernunft) é aquele que se opera «sem crítica prévia do seu poder próprio» (ohne vorangehende Kritik ihres eigenen Vermögens). Cf. Immanuel KANT, Kritik der reinen Vernunft, Vorrede zur zweiten Auflage; B XXXV.

${ }^{20}$ É «dogmática» (dogmatisch) aquela filosofia que «põe no mesmo plano, e contrapõe, algo em si ao Eu» (dem Ich an sich etwas gleich-und entgegensetzt). Cf. FICHTE, Grundlage der gesammten Wissenschaftslehre als Handschrift für seine Zuhörer (1794), I, § 3; Sämmtliche Werke, ed. Immanuel Hermann Fichte (doravante: SW), reprod. Berlin, Walter de Gruyter \& Co., 1971, vol. I, p. 119. 
então, entende Stirner, a radicalidade demandada terá de aportar a camadas muito mais fundas da interioridade:

O Teu pensar não tem "o pensar" como pressuposição [Voraussetzung], mas [tem-te] a Ti. [...]. Antes do meu pensar sou - Eu. [...]. Pois, a pressuposição que Eu sou para o meu pensar não é nenhuma [pressuposição] feita pelo pensar, nenhuma [pressuposição] pensada, mas é o próprio pensar posto, é o dono [Eigner] do pensar, e prova apenas que o pensar não é mais do que propriedade [Eigentum], isto é, que não existe de todo um pensar "autónomo", um "Espírito pensante"21.

\section{§ 2. A fundacionalidade do «eu»}

O sinal próximo para a necessidade de expedições sertanejas, ou de «viagens filosóficas», aos territórios da subjectividade havia sido dado já por Bruno Bauer, com a sua transfiguração de motivos hegelianos ${ }^{22}$ na apoteose da «autoconsciência» (Selbstbewußtsein) crítica face às dominações petrificadas da «substancialidade»:

a substância [Substanz] é apenas o fogo momentâneo em que o eu sacrifica a sua finitude [Endlichkeit] e limitidade [Beschränktheit]. A conclusão do movimento não é a substância, mas a autoconsciência [Selbstbewußtsein], que se pôs realmente como infinita e tomou em si a universalidade da substância como essência sua. A substância é apenas o poder [Macht] que consome a finitude do eu e cabe depois como despojo [Beute] à autoconsciência infinita ${ }^{23}$.

21 «Dein Denken hat nicht "das Denken” zur Voraussetzung, sondern Dich. [...] Vor meinem Denken bin - Ich. [...] Denn die Voraussetzung, welche Ich für mein Denken bin, ist keine vom Denken gemachte, keine gedachte, sondern ist das gesetzte Denken selbst, ist der Eigner des Denkens, und beweist nur, daß das Denken nichts weiter ist, als Eigentum, d. h. daß ein "selbständiges" Denken, ein “denkender Geist" gar nicht existiert.», STIRNER, EE, 2, II, 3; p. 395.

22 Relativamente a uma compreensão dialéctica de que «a substância é essencialmente sujeito» - «die Substanz wesentlich Subjekt ist»-, veja-se, por exemplo: HEGEL, Phänomenologie des Geistes, Vorrede; TW, vol. 3, p. 28.

23 «Die Substanz ist nur das momentane Feuer, in welchem das Ich seine Endlichkeit und Beschränktheit opfert. Der Schluß der Bewegung ist nicht die Substanz, sondern das Selbstbewußtsein, welches sich wirklich als unendlich gesetzt und die Allgemeinheit der Substanz als sein Wesen in sich aufgenommen hat. Die Substanz ist nur die Macht, welche die Endlichkeit des Ich aufzehrt und dem unendlichen Selbstbewußtsein dann zur Beute anheimfällt.», Bruno BAUER, Die Posaune des jüngsten Gerichts über Hegel den Atheisten und Antichristen (1841), I; Die Hegelsche Linke. Dokumente zu Philosophie und Politik im deutschen 
Com um interesse de partida que não releva imediatamente da busca de fundamentação para uma problemática de teoria do conhecimento (onto-gnosiológica ou onto-epistemológica), e sem um desígnio de chegada apontado a uma Sittlichkeit comunitária (traços nitidamente perceptíveis na inquirição da racionalidade, patente, por exemplo, em Kant e em Fichte), o caminho que Stirner trata de empreender retoma - por isso mesmo, e porque se revestirá de uma outra tonalidade específica: apenas em certa medida - as colocações, em clave egóica e accionalista, típicas do idealismo alemão anterior à sua reconfiguração hegeliana.

No quadro fundante do seu idealismo transcendental, Kant havia, com acuidade crítica, acenado já para o novo território de investigação a desbravar, que, num mesmo movimento, se passava a estender.

Toda a consciência representativa, em geral, supõe kantianamente de acordo com a «Analítica transcendental» da Kritik der reinen Vernunft - uma «vinculação» (Verbindung), ou uma «conjunção» (coniunctio), originária ${ }^{24}$, sem a qual não haveria nem referência a um objecto, em geral, nem determinação transcendental do conhecido no conhecer, nem, de entrada, a possibilidade de essa consciência ser reconhecida como minha.

Nestes termos, portanto, e como fundamento transcendental da teoria kantiana do juízo: "O eu penso [das: Ich denke] tem que poder acompanhar todas as minhas representações [Vorstellungen]; pois, de contrário, seria representado em mim algo [etwas] que de todo não poderia ser pensado, o que significaria ou que a representação seria impossível, ou que, pelo menos, não seria nada para mim. $»^{25}$.

Por sua vez, esta ligação transcendental a priori encontra-se montada sobre a «unidade originariamente sintética da apercepção» (ursprünglich synthetische Einheit der Apperzeption $)^{26}$ que, enquanto sujeito

Vormärz, ed. Heinz e Ingrid Pepperle (doravante: HL), Leipzig, Philipp Reclam jun., 1985, p. 287.

Não é sem razão que Marx entenderá a Selbstbewußtsein de Bruno Bauer, nos seus desenvolvimentos doutrinais subsequentes, como «a caricatura metafisico-teológica do ser humano na sua separação relativamente à Natureza» - «die metaphysisch-theologische Karikatur des Menschen in seiner Trennung von der Natur», ENGELS - MARX, Die heilige Familie, oder Kritik der kritischen Kritik. Gegen Bruno Bauer und Konsorten (1845), VI, 3, f; MEW, vol. 2, p. 146.

${ }^{24}$ Cf. KANT, Kritik der reinen Vernunft, transzendentale Analytik, I, 2, 2, § 15; B 129.

25 «Das: Ich denke, muß alle meine Vorstellungen begleiten können; denn sonst würde etwas in mir vorgestellt werden, was gar nicht gedacht werden könnte, welches eben soviel heißt, als die Vorstellung würde entweder unmöglich, oder wenigstens für mich nichts sein.», KANT, Kritik der reinen Vernunft, transzendentale Analytik, I, 2, 2, § 16; B 131-132.

26 «A unidade transcendental da apercepção é aquela pela qual é reunido num con- 
transcendental em si indeterminado (porque fonte e suporte de toda a determinação), não constitui nem uma «substância» nem uma «coisa» - de onde a crítica dos paralogismos da «substancialidade da alma» -, mas corresponde a «um acto da espontaneidade da força [ou da faculdade] de representação» (ein Actus der Spontaneität der Vorstellungskraft) ${ }^{27}$ :

Mediante este Eu [Ich], ou Ele [Er], ou Isso [Es] (a coisa) [das Ding], que pensa, não se representa nada além de um sujeito transcendental dos pensamentos $=\mathrm{x}$, o qual só é conhecido através dos pensamentos que são predicados seus, e do qual, separadamente, nós nunca podemos ter o menor conceito $^{28}$.

Para Kant, no acto originário em que esta função sintética irrompe, não tenho, por conseguinte, consciência de aquilo que sou - o que suporia uma objectivação empírica de conteúdos, ou uma constituição transcendental de determinações -, mas apenas tenho consciência de que sou, como operação espontânea fundadora da «síntese», em geral. Como na «Analítica transcendental» da primeira Crítica igualmente se trata de precisar, evacuando quaisquer eventuais pretensões introspectivas «psicologistas» ou «ontologificadoras»:

Pelo contrário, na síntese transcendental do diverso das representações, em geral, portanto, na unidade sintética originária da apercepção, sou consciente de mim próprio, não tal como eu me apareço [nicht wie ich mir erscheine], nem tal como eu em mim próprio sou [noch wie ich an mir selbst bin], mas apenas [sou consciente] de que eu sou $[\text { nur daß ich bin }]^{29}$.

ceito de objecto todo o diverso dado numa intuição. Ela chama-se, por isso, objectiva, e tem que ser diferenciada da unidade subjectiva da consciência, que é uma determinação do sentido interno pela qual esse diverso da intuição é dado empiricamente para uma tal vinculação.» - «Die transzendentale Einheit der Apperzeption ist diejenige, durch welche alles in einer Anschauung gegebene Mannifaltige in einen Begriff vom Objekt vereinigt wird. Sie heißt darum objektiv, und muß von der subjektiven Einheit des Bewußtseins unterschieden werden, die eine Bestimmung des inneren Sinnes ist, dadurch jenes Mannifaltige der Anschauung $\mathrm{zu}$ einer solchen Verbindung empirisch gegeben wird.», KANT, Kritik der reinen Vernunft, transzendentale Analytik, I, 2, 2, § 18; B 139.

27 Cf. KANT, Kritik der reinen Vernunft, transzendentale Analytik, I, 2, 2; B 130.

28 «Durch dieses Ich, oder Er, oder Es (das Ding), welches denket, wird nun nichts weiter, als ein tranzendentales Subjekt der Gedanken vorgestellt $=\mathrm{x}$, welches nur durch die Gedanken, die seine Prädikate sind, erkannt wird, und wovon wir, abgesondert, niemals den mindesten Begriff haben können», KANT, Kritik der reinen Vernunft, transzendentale Dialektik, II, 1; A 346, B 404.

29 «Dagegen bin ich mir meiner selbst in der transzendentalen Synthesis des 
Fichte, por seu turno - sobretudo a partir da Wissenschaftslehre de 1794 -, irá proceder a uma integração doutrinal, e a um novo ensaio de reconstrucção doutrinária, desta perspectiva inaugurante.

«O princípio fundamental absolutamente primeiro, pura e simplesmente incondicionado, de todo o saber humano» (der absolut-erste, schlechthin unbedingte Grundsatz alles menschlichen Wissens) descobre-se, deste modo, como a Thathandlung - a «acção» auto-instituinte que, do mesmo passo, é «facto» de instituição - que «subjaz como fundamento a toda a consciência, e somente a torna possível» (allem Bewusstseyn zum Grunde liegt, und allein es möglich macht $)^{30}$.

Esta Thathandlung originária e radicante - por onde não deixam de reverberar todos os harmónicos modernos e setecentistas que se condensam no fáustico «No começo era o acto!» (Im Anfang war die That!) ${ }^{31}$ - firma-se e afirma-se, de entrada, como a auto-posição do eu, ou «o pôr[-se] do eu por si próprio» (das Setzen des Ich durch sich selbst) como «a actividade pura» (die reine Thätigkeit), de que o «eu sou» [Ich bin] constitui «expressão» (Ausdruck) primeira, e em que «acção e facto são um e precisamente o mesmo» (Handlung und That sind Eins und ebendasselbe) ${ }^{32}$.

Tanto o «Eu» na sua empiricidade, como o «Não-Eu mundano», do mesmo modo que a sua respectiva articulação numa consciência intencional determinada, devêm, nestes termos e em conformidade, produto e resultado de uma acção originária do «Eu» absoluto $^{33}$, de que importa em toda a sua implicação tomar posse, sob pena de resvalamento para e de queda no «dogmatismo», em que a esfera constitutiva da «imanência» se passaria a ver subordinada à dominação (alienante) de uma materialidade

Mannigfaltigen der Vorstellungen überhaupt, mithin in der synthetischen ursprünglichen Einheit der Apperzeption, bewußt, nicht wie ich mir erscheine, noch wie ich an mir selbst bin, sondern nur $d a \beta$ ich bin.», KANT, Kritik der reinen Vernunft, transzendentale Analytik, I, 2, 2, § 25; B 157.

${ }^{30}$ Cf. FICHTE, Grundlage der gesammten Wissenschaftslehre (1794), I, §1; SW, vol. I, p. 91.

31 Cf. GOETHE, Faust, I, Studirzimmer, 1237; WW, vol. 14, p. 63.

${ }^{32}$ Cf. FICHTE, Grundlage der gesammten Wissenschaftslehre (1794), I, §1; SW, vol. I, p. 96.

33 «O Eu assim como o Não-Eu são ambos produtos de acções originárias do Eu, e a própria consciência é um tal produto da primeira acção originária do Eu, do pôr[-se] do Eu por si próprio.» - «Das Ich sowohl, als das Nicht-Ich sind beides Producte ursprünglicher Handlungen des Ich, und das Bewusstseyn selbst ist ein solches Product der ersten ursprünglichen Handlung des Ich, des Setzens des Ich durch sich selbst.», FICHTE, Grundlage der gesammten Wissenschaftslehre (1794), I, $\S 3$; SW, vol. I, p. 107. 
«transcendente» ${ }^{34}$, que acabaria por desvanecer e aniquilar a «liberdade» constituinte.

Todos estes posicionamentos teoréticos que respiram num rarefeito ambiente de abstracção se encontram, porém, para Fichte, suspensos de uma atiutude ético-vivencial determinante que, em caso algum, é conveniente escamotear:

Aquilo que se escolha como filosofia depende, por conseguinte, de aquilo que se é como ser humano: pois, um sistema filosófico não é um mobiliário morto [ein todter Hausrath] de que uma pessoa se possa desembaraçar, ou aceitar, como lhe aprouver, mas ele está animado pela própria alma do ser humano que o tem ${ }^{35}$.

O programa fichteano para um relançamento crítico da filosofia vem, assim, a comportar expressamente elementos e motivos com que nos voltaremos a deparar, num registo transfigurado, em Max Stirner.

$\mathrm{O}$ arranque da primeira introdução à Wissenschaftslehre revela-se-nos, sob este ângulo, particularmente significativo: «Repara em ti próprio [merke auf dich selbst]: varre o teu olhar de tudo o que te rodeia e vira-te para o teu interior [in dein Inneres] - é a primeira exigência que a filosofia faz ao aprendiz dela. Não se trata de nada que está fora de ti, mas principalmente de ti próprio [von dir selbst].» ${ }^{36}$

$\mathrm{Na}$ conhecida tradição agostiniana - de que a religiosidade reformada haveria de operar a recuperação e o aprofundamento -, o «permanece em ti próprio» (in teipsum redi) ${ }^{37}$ configurava a imperativa e privilegiada

34 «No sistema crítico, a coisa é o [que é] posto no Eu; no [sistema] dogmático, é aquilo em que o próprio Eu é posto: o criticismo é, portanto, imanente, porque põe tudo no $\mathrm{Eu}$; o dogmatismo [é] transcendente, porque vai ainda para além do Eu.» - «Im kritischen Systeme ist das Ding das im Ich gesetzte; im dogmatischen dasjenige, worin das Ich selbst gesetzt ist: der Kriticism ist darum immanent, weil er alles in das Ich setzt; der Dogmatism transcendent, weil er noch über das Ich hinausgeht.», FICHTE, Grundlage der gesammten Wissenschaftslehre (1794), I, § 3; SW, vol. I, pp. 119-120.

35 «Was für eine Philosophie man wähle, hängt sonach davon ab, was man für ein Mensch ist: denn ein philosophisches System ist nicht ein todter Hausrath, den man ablegen oder annehmen könnte, wie es uns beliebte, sondern es ist beseelt durch die Seele des Menschen, der es hat.», FICHTE, Erste Einleitung in die Wissenschaftslehre (1797), 5; SW, vol. I, p. 434.

36 «Merke auf dich selbst: kehre deinen Blick von allem was dich umgiebt, ab, und in dein Inneres - ist die erste Forderung, welche die Philosophie an ihren Lehrling thut. Es ist von nichts, was ausser dich ist, die Rede, sondern lediglich von dir selbst.», FICHTE, Erste Einleitung in die Wissenschaftslehre (1797), 1; SW, vol. I, p. 422.

37 «Não vás fora; permanece em ti próprio; a verdade habita no homem interior.» - «Noli foras ire; in teipsum redi; in interiore homine habitat veritas.», Aurélio AGOSTINHO, De vera religione, 39, 72. 
descoberta da «transcendência» divina na própria intimidade da consciência crente. Agora, pelo contrário, é no vector, e no dinamismo próprio, de uma egoidade instauradora - porque «auto-instauradora» - que a atenção se encontra primordialmente focalizada.

Com efeito, este incitamento fichteano repousa sobre, e dele deriva, toda uma coincidência de «agir» e de «ser» que o filósofo é chamado a empreeender, no âmbito de um projecto de auto-edificação egóica que lhe desenha e desdobra um espaço «arbitrário» - porque «espontâneo» - de liberdade, que reclama ocupação.

Como, a propósito do filósofo, na segunda introdução à «doutrina da ciência», se precisa: "Aquele Eu construindo-se a si próprio [sich selbst construirende Ich] não é senão o seu próprio [sein eigenes]. Ele [o filósofo] só nele próprio pode intuir o indicado acto $[A c t]$ do Eu» - no contexto, trata-se da re-flexão ou da viragem para a interioridade, em que o «Eu» devém originariamente para si próprio - «e, para o poder intuir [anschauen], ele tem que o completar [ou executar, vollziehen]. Ele produ-lo [hervorbringen] nele próprio [no filósofo], arbitrariamente e com liberdade [willkürlich und mit Freiheit].» ${ }^{38}$

\section{§ 3. Uma peculiar reinstalação da forma egóica}

Todos estes motivos e todas estas perspectivas que de longe vinham aparelhando um solo enraizador para a filosofia (em especial, na Alemanha) se encontram, na realidade, presentes e actuantes, transformadamente, no pensamento de Stirner.

É sobre estes «escombros» (Trümmer) - para lembrar a conhecida metafáfora de que Kant se servia nos seus $\operatorname{cursos}^{39}$ - do idealismo alemão, pré-hegeliano e pós-hegeliano, que Stirner irá proceder à sua edificação teorética, em regime egóico e accionalista, procurando, na envolvência dessa paisagem, o seu caminho próprio.

38 «Jenes sich selbst construirende Ich ist kein anderes, als sein eigenes. Er kann den angegebenen Act des Ich nur in sich selbst anschauen, und um ihn anschauen zu können, muss er ihn vollziehen. Er bringt ihn willkürlich und mit Freiheit in sich hervor.», FICHTE, Zweite Einleitung in die Wissenschaftslehre, für Leser, die schon ein philosophisches System haben (1797), 4; SW, vol. I, pp. 459-460.

39 «Cada pensador filosófico constrói, por assim dizer, sobre os escombros de uma outra [obra] a sua obra própria» - «Jeder philosophische Denker baut, so zu sagen, auf den Trümmern eines andern sein eigenes Werk», KANT, Logik, ein Handbuch zu Vorlesungen (1800), Einleitung, III; Gesammelte Schriften, ed. Königlich Preussische Akademie der Wissenschaften (Ak.), Berlin - Leipzig, Walter de Gruyter \& Co., 1923, vol. IX, p. 25. 
Com alta probabilidade, este percurso não terá sido realizado a partir de uma rebuscada confrontação filológica directa com estes textos fundadores, mas mediado antes por todas as complexas (e acaloradamente debatidas) vicissitudes que haviam acompanhado, entre os círculos da juventude alemã pensante da altura, a conturbada procura das maneiras tempestivas para continuar a fazer filosofia depois de Hegel $^{40}$.

Sempre no quadro de um desiderato de intervenção crítica nas condições alemãs do Vormärz, no sentido da promoção de uma liberdade esclarecida, é, na verdade, como demanda dos caminhos novos para uma filosofia nova que podemos surpreender, nesse período, toda uma panóplia de chamadas de atenção para a relevância das vertentes que se prendem com a «accionalidade», com o «acto», com a «práxis» - de August von Cieszkowski ${ }^{41}$ a Moses Hess ${ }^{42}$, passando incontornavelmente por Feuerbach ${ }^{43}$ e pelos irmãos Bauer ${ }^{44}$, e sem esquecer, já agora, os acutilan-

40 Podemos, porventura, entre muitos outros exemplos na época disponíveis, encontrar num artigo de Arnold Ruge, publicado nos Hallische Jahrbücher em 1840, uma ilustração sintomática desta leitura perspectivante dos «sinais dos tempos»: «A forma da religião não está completada em Cristo, a da poesia não [o está] em Goethe, a da filosofia não [o está] em Hegel; eles todos são tão pouco o final do Espírito que, antes, têm a sua maior honra em terem sido o começo de um novo desenvolvimento.» - «Nicht in Christus ist die Form der Religion, nicht in Goethe die der Poesie, nicht in Hegel die der Philosophie vollendet; alle sind so wenig das Ende des Geistes, daß sie vielmehr ihre größte Ehre darin haben, der Anfang einer neuen Entwicklung zu sein.», Arnold RUGE, Zur Kritik des gegenwärtigen Staats-und Völkerrechts (1840); HL, p. 154.

41 «Ser e pensar têm, portanto, que afundar-se no agir - a arte e a filosofia [têm que afundar-se] na vida social -, para só lá emergirem e florescerem de novo verdadeiramente e em conformidade com a sua determinação última.» - «Seyn und Denken muss also im Thun, - Kunst und Philosophie im socialen Leben, - zu Grunde gehen, um dort erst wieder wahrhaft und ihrer letzten Bestimmung gemäss aufzutauchen und aufzublühen.», August von CIESZKOWSKI, Prolegomena zur Historiosophie (1838), III; ed. Rüdiger Bubner, Hamburg, Felix Meiner Verlag, 1981, p. 112.

42 Num texto publicado nas Einundzwanzig Bogen aus der Schweiz, em que a crítica do cogito ergo sum cartesiano vai a par de uma expressa revalorização dos posicionamentos de Fichte, Hess trata de deixar bem vincado que «não o ser, mas o acto, é o primeiro e último» («nicht das Sein, sondern die That ist das Erste und Letzte»), pelo que «a tarefa da filosofia do Espírito é agora tornar-se filosofia do acto. Não apenas o pensar, mas toda a actividade humana, tem que ser elevada a esse ponto de vista, em que todos os opostos desaparecem.»- «Es ist jetzt die Aufgabe der Philosophie des Geistes, Philosophie der That zu werden. Nicht nur das Denken, sondern die ganze menschliche Thätigkeit muß auf jenem Standpunkt erhoben werden, wo alle Gegensätze schwinden.», Moses HESS, Philosophie der That (1843); PSS, respectivamente, pp. 210 e 219.

43 «A filosofia nova, pelo contrário, como a filosofia do ser humano, é também es- 
tes reparos críticos que o jovem Marx, desde bem cedo, e apontando a uma funda compreensão ontológica da prática, não deixou de ir dirigindo contra os diversificados intentos circundantes de diluição da materialidade do real e de exclusiva subjectivação interiorizada do agir ${ }^{45}$.

sencialmente a filosofia para o ser humano; ela tem, sem prejuízo da dignidade e autonomia da teoria, mais: no mais íntimo uníssono com ela, essencialmente uma tendência prática, e mesmo uma tendência prática em sentido supremo; ela entra para o lugar da religião, tem nela a essência da religião, ela é, na verdade, propriamente religião.» - «Die neue Philosophie dagegen, als die Philosophie des Menschen, ist auch wesentlich die Philosophie für den Menschen; sie hat, unbeschadet der Würde und Selbständigkeit der Theorie, ja, im innigsten Einklang mit derselben, wesentlich eine praktische, und zwar im höchsten Sinne praktische, Tendenz; sie tritt an die Stelle der Religion, sie hat das Wesen der Religion in sich, sie ist in Wahrheit selbst Religion.», FEUERBACH, Grundsätze der Philosophie der Zukunft (1843), § 66; GW, vol. 9, p. 340.

44 «A nossa prática é o nosso conhecimento, que nos dissolve todos os enganos com que a religião se embala acerca de si própria. A teoria libertou-nos dessas ilusões - [libertou-nos] da própra religião.» - «Unsere Praxis ist die Erkenntnis, die uns alle Täuschungen, welche die Religion sich über sich selbst vormacht, auflöst. Die Theorie hat uns von diesen Illusionen - von der Religion selbst befreit.», Bruno BAUER, Die gute Sache der Freiheit und meine eigene Angelegenheit (1842), 11; HL, p. 506.

«O meio de nos tornarmos livres é a crítica: ela expulsa as fraquezas, e a fé, e a humildade pequeno-burguesa. Ela mostra que o ser humano tem de criar e de dominar as relações, não as relações o ser humano.» - «Das Mittel, uns frei zu machen, ist die Kritik: sie vertreibt Schwäche und Glauben und spießbürgerliche Demut. Sie zeigt, daß der Mensch die Verhältnisse, nicht die Verhältnisse den Menschen zu schaffen und zu beherrschen haben.», Edgar BAUER, Der Streit der Kritik mit Kirche und Staat (1843); HL, pp. 582-583.

45 Como numa carta a Feuerbach se refere, a propósito de uma caracterização da atitude enformadora dos escritos de Bruno Bauer na Berliner Litteraturzeitung: «A Crítica é transformada num ser transcendente. Aqueles berlinenses não se têm por seres humanos que criticam, mas por críticos que, ao lado disso, têm a infelicidade de serem seres humanos. Eles reconhecem, por isso, apenas uma necessidade [Bedürfnis] real, a necessidade da crítica teórica. A gente como Proudhon é, por isso, censurado que tome o seu ponto de partida de uma "necessidade" "prática". Esta Crítica transcorre, por isso, num espiritualismo triste e afectado. A consciência, ou a autoconsciência, é considerada como a única qualidade humana. O amor, por exemplo, é negado, porque nele a amada seria apenas "objecto". Abaixo o objecto! Esta Crítica tem-se, por isso, pelo único elemento activo da história.»«Die "Kritik" wird in ein transcendentes Wesen verwandelt. Jene Berliner halten sich nicht für Menschen, die kriticiren, sondern für Kritiker, die nebenbei das Unglück haben, Menschen zu sein. Sie erkennen daher nur ein wirkliches Bedürfniß an, das Bedürfniß der theoretischen Kritik. Leuten wie Proudhon wird daher vorgeworfen, daß sie ihren Ausgangspunkt von einem "praktischen" "Bedürfniß" nehmen. Diese Kritik verläuft sich daher in einen traurigen und vornehmthuenden 
Relativamente ao tópico que nos ocupa, e tendo em conta o panorama do mercado de ideias em que se inscrevia, o específico da posição stirneriana assoma na maneira peculiar por que entende tanto a primordialidade da imanência - esse «nada» de transcendências do qual tudo o mais tem que decorrer -, como o teor ou cunho da egoidade que aí desponta, e que a primeiro (ou único) plano das considerações tem que ser alçada.

Desmontando criticamente a abordagem idealista moderna inaugurada por Descartes, e os seus reflexos teológico-religiosos numa consciência devota luteranamente reformada, Stirner insistirá em que a forma egóica que nesse âmbito vem à luz se encontra ainda prisioneira de uma «celestialidade» de pensamento que, designadamente, se traduz na tese segundo a qual «Eu» me circunscrevo a ser «espírito» - esclarecidamente pensante (e, porventura, ate $\left.{ }^{46}\right)$, ou piedosamente crente.

Por esta via de redução - que, na «imanência» reivindicada, tão-só acaba por substituir uma «transcendência» por outra - se apaga, ou reprime, do mesmo passo, tudo aquilo que a esse empolamento espiritualizado decididamente escapa: a carnalidade do corpo com os seus padecimentos e pulsões ${ }^{47}$.

Spiritualismus. Das Bewußtsein oder Selbstbewußtsein wird als die einzige menschliche Qualität betrachtet. Die Liebe z. B. wird geläugnet, weil in ihr die Geliebte nur "Gegenstand" sei. À bas mit dem Gegenstand! Diese Kritik hält sich daher für das einzige active Element der Geschichte.», MARX, Brief an Ludwig Feuerbach, 11. August 1844; MEGA $^{2}$, vol. III/1, pp. 64-65.

46 Preparando aquilo que virá a ser uma crítica das hipostasiações fílosóficas da «Razão» (Vernunft), Stirner, num artigo de 1842 para a Rheinische Zeitung, não deixará de assinalar que «a Razão, o Espírito da Filosofia, se ocupa apenas de si própria, e não se preocupa com objecto nenhum. Para o filósofo, deus é tão indiferente como uma pedra: ele é o ateu mais consumado.» - «Die Vernunft, der Geist der Philosophie, beschäftigt sich nur mit sich selbst, und kümmert sich um kein Objekt. Dem Philosophen ist Gott so gleichgültig, als ein Stein: er ist der ausgemachteste Atheist.», STIRNER, Kunst und Religion (1842); KS, p. 268.

${ }^{47}$ Fazendo o ponto - e sugerindo o contraponto - dessas concepções, salienta Stirner: «Em suma, o Meu ser (o sum) é uma vida no Céu do pensar, do espírito, um cogitare. Eu próprio, porém, não sou senão espírito, como [espírito] pensante (segundo Descartes), como crente (segundo Lutero). O Meu corpo [orgânico, Leib], isso não sou Eu; a Minha carne [Fleisch] pode padecer de apetites ou tormentos. Eu não sou a Minha carne, mas Eu sou espírito, apenas espírito.» - «Kurz Mein Sein (das sum) ist ein Leben im Himmel des Denkens, des Geistes, ein cogitare. Ich selber aber bin nichts anderes als Geist, als denkender (nach Cartesius), als Gläubiger (nach Luther). Mein Leib, das bin Ich nicht; Mein Fleisch mag leiden von Gelüsten oder Qualen. Ich bin nicht Mein Fleisch, sondern Ich bin Geist, nur Geist.», STIRNER, EE, 1, II, 2, § 3; p. 92. 
Deparamo-nos, assim, com uma cisão que remove de mim uma parte considerável de aquilo que sou (e não é, como tal, reconhecido), e que chega mesmo a levantar-me na minha interioridade contra mim próprio: «O protestante consiste neste rasgamento [Zerrissenheit] do ser humano em "impulso de Natureza" [Naturtrieb] e "consciência [moral, Gewissen]" (plebe interior e polícia interior).» ${ }^{48}$

Assentar a integridade do «Eu», contra todos os dualismos que secretamente o dilaceram, não se apresenta todavia como bastante. É preciso reinstalar o «Eu», na sua inteireza refeito, na genuína majestade que, em próprio, lhe cabe.

É preciso, por isso e para isso, despi-lo ainda de qualquer figura de «universalidade» que lhe tenha permanecido colada, ou preguiçosamente a arrastar. Há, pois, que combater com denodo qualquer vislumbre enganador de que por detrás do ombro do «eu» lhe espreite ainda a silhueta baça de algum «nós» - designadamente, enfaixado em roupagens de «Razão» (Vernunft) ${ }^{49}$ (como acaba por acontecer nos diversos figurinos kantiano, fichteano e hegeliano), ou reintroduzido e introjectado de contrabando, ao jeito do criticado Feuerbach, como um «Além em Nós» (Jenseits in Uns), em que a divindade, expulsa da sua «morada celeste» (himmlische Wohnung), se translada «de armas e bagagens» (mit Sack und Pack $)^{50}$ para «o ser humano» (der Mensch) ou para uma «humanidade» (Menschheit) re-sacralizados. E daí o reparo interrogativo: "Como podeis vós acreditar que o deus-homem [der Gottmensch] morreu, antes de que nele, além do deus, também o Homem [der Mensch] tenha morrido?» ${ }^{51}$.

É preciso, por isso e para isso, remeter o «Eu» à singularidade visceralmente irreprodutível - em cada caso e a cada momento, necessária, como o suporte autêntico, e insubstituível, da imanência devidamente entendida na sua radicalidade e radicação. Stirner está decerto disposto a reconhecer, com Fichte, que o pensar é função de uma accionalidade do «Eu», e até, com Feuerbach, que é na Sinnlichkeit que o segredo recuperado do «ser» se entrega; «Só que, para o pensar, tal como para o sentir

48 «In dieser Zerrissenheit des Menschen in "Naturtrieb" und "Gewissen" (innerer Pöbel und innere Polizei) besteht der Protestant.», STIRNER, EE, 1, II, 2, § 3; p. 97.

49 «Nem a razão divina, nem a [razão] humana, é [efectivamente] real, mas somente a tua e a minha razão, de cada vez, como e porque Tu e e Eu o somos.» - «Weder die göttliche noch die menschliche Vernunft, sondern allein deine und meine jedesmalige Vernunft ist wirklich, wie und weil Du und Ich es sind.», STIRNER, EE, 2, II, 1; p. 225.

${ }^{50}$ Cf. STIRNER, EE, 1, II, 2, § 1; p. 35.

51 «Wie mögt Ihr glauben, daß der Gottmensch gestorben sei, ehe an ihm außer dem Gott auch der Mensch gestorben ist?», STIRNER, EE, 2; p. 170. 
[Empfinden] - portanto, para o abstracto, tal como para o sensível -, Eu preciso, antes de todas as coisas, de Mim, e, sem dúvida, de Mim [enquanto] este [algo de] totalmente determinado, de Mim [enquanto] este único.» ${ }^{52}$.

É preciso, por isso e para isso, desvendar - e, fundamentalmente, assumir - o «Eu» na dinâmica transiente, hetero- e auto-dirigida, de engendramento e de destruição, que, desembaraçando-se de qualquer vestígio de uma antiga e arreigada «consciência coisal» (dingliches Bewußtsein) ${ }^{53}$, em rigor, o «des-substancializa», «des-coisifica», ou «des-entifica», posto que a im-permanência da sua obra e do seu obrar representa o selo do próprio «nada» em que con-siste e in-siste:

Quando Fichte diz: "o Eu é tudo" 54 , isto parece harmonizar-se perfeitamente com as minhas colocações. Somente, não é o Eu [que é] tudo, mas o Eu destrói tudo, e só o Eu que ele próprio se dissolve, o Eu que nunca é [das nie seiende Ich], o Eu finito, é realmente Eu. Fichte fala do Eu "absoluto", eu, porém, falo de Mim, do Eu transitório [vergängliches Ich $]^{55}$.

Pelas veredas desta aparente limitação, aqui irrompe o ideal stirneriano apoteótico de uma transitoriedade original e originante, que recusa todas as «ideias fixas» ${ }^{56}$ indutoras de servidão ao "poder de algo de alheio» (Macht eines Fremden) ${ }^{57}$ e que recusa ela própria fixar-se em qualquer determinação que lhe vincule um destino ou prescreva uma missão ${ }^{58}$.

52 «Allein zum Denken wie zum Empfinden, also zum Abstrakten wie zum Sinnlichen brauche Ich vor allen Dingen Mich, und zwar Mich, diesen ganz Bestimmten, Mich diesen Einzigen.», STIRNER, EE, 2, II, 3; p. 382.

53 Cf. STIRNER, EE, 1, II, 2, § 3; p. 89.

54 «Tudo o que é para o Eu é através do Eu.» - «Alles, was für das Ich ist, ist durch das Ich.», FICHTE, Zweite Einleitung in die Wissenschaftslehre (1797), 1; SW, vol, I, p. 455.

As afirmações que vão no mesmo sentido são múltiplas. A título ilustrativo: «O Eu é fonte de toda a realidade.» - «Aller Realität Quelle ist das Ich.», FICHTE, Gundlage der gesammten Wissenschaftslehre (1794), II, § 4, C; SW, vol. I, p. 134.

55 «Wenn Fichte sagt: "Das Ich ist Alles”, so scheint dies mit meinen Aufstellungen vollkommen $\mathrm{zu}$ harmonieren. Allein nicht das Ich ist Alles, sondern das Ich zerstört Alles, und nur das sich selbst auflösende Ich, das nie seiende Ich, das endliche Ich ist wirklich Ich. Fichte spricht vom "absoluten" Ich, Ich aber spreche von Mir, dem vergänglichen Ich.», STIRNER, EE, 2, II; p. 199.

56 «Sim, as "ideias fixas" é o verdadeiramente sagrado!» - «Ja, die "fixe Ideen”, das ist das wahrhaft Heilige!», STIRNER, EE, 1, II, 2, § 2; p. 47.

${ }^{57}$ Cf. STIRNER, EE, 1, II, 2, § 3; p. 77.

58 «Um ser humano não está "vocacionado" para nada e não tem nenhuma "tarefa", nenhuma "destinação", tão-pouco quanto uma planta ou um animal têm uma 
Está, assim, em marcha - na circunstância, ao ritmo de uma cadência pomposa - a celebração em clave egóica, não do simples «vazio» ou da «vacuidade» (Leerheit), mas daquele «nada criador [schöpferisches Nichts], o nada a partir do qual eu próprio como criador [Schöpfer] tudo crio» ${ }^{59}$. É, pois, a este «Nada» que irremediavelmente há sempre que volver, a cada momento tornado originário ${ }^{60}$, pois essa é a marca indelével da condição - da ocupação insubstituível de um «espaço» (interior) que todo este discurso toma como objecto central de evidenciação.

Penso ser esse, de resto, o sentido genuíno de uma das afirmações do final do livro, e que, no fundo, resume a intenção que em todo ele se explicita: «No único, o dono [Eigner] regressa ele próprio ao seu nada criador, do qual nasceu» ${ }^{61}$. Fazer do «Nada» a minha «causa» - é fazer de «Mim» a «causa» única.

\section{§ 4. Fazer-se}

Com a invocação deste «nada criador», passa a ficar assim descoberto e desdobrado o território interpelante que importa ocupar, de que importa tomar posse, em que importa «activar-se».

É deste «nada», assim entendido, que, por consequência, se desprende e eleva - alegadamente, não como «dever-ser» $(\text { Sollen })^{62}$ reitor de

"vocação".» - «Ein Mensch ist zu nichts "berufen" und hat keine "Aufgabe", keine "Bestimmung", so wenig als eine Pflanze oder ein Tier einen "Beruf" hat.», STIRNER, EE; 2, II, 3; p. 366.

59 «Das schöpferische Nichts, das Nichts, aus welchem Ich selbst als Schöpfer Alles schaffe», STIRNER, EE, Ich hab' Mein Sach' auf Nichts gestellt; p. 5.

Como, mais adiante, se dirá: «Eu, este nada, farei brotar de Mim as minhas criações.»- «Ich, dieses Nichts, werde meine Schöpfungen aus Mir hervortreiben.», STIRNER, EE, 2, II, 2; p. 259.

60 Sobre a necessidade de activar a auto-posição peremptória, a cada «momento» (Moment) ou a cada «instante» (Augenblick), como instauração de que, só aí, «Eu sou», veja-se, por exemplo: STIRNER, EE, 1, II, 3,§ 3; p. 167.

Como repetidamente, em múltiplas passagens, se insiste: «só no instante Tu és Tu, só como [algo de] instantâneo Tu és realmente» - «nur im Augenblicke bist Du Du, nur als Augenblicklicher bist Du wirklich», STIRNER, Recensenten Stirners (1845); KS, p. 369.

61 «Im Einzigen kehrt selbst der Eigner in sein schöpferisches Nichts zurück, aus welchem er geboren wird.», STIRNER, EE, 2, III; p. 412.

62 «Sob a religião e a política, o ser humano encontra-se», tanto perante os outros como perante si próprio, «no ponto de vista do dever-ser: ele deve tornar-se isto e aquilo, deve ser assim e assim.» - «Unter Religion und Politik befindet sich der Mensch auf dem Standpunkte des Sollens: er soll dies und das werden, soll so und so sein.», STIRNER, EE, 2, II, 2; p. 268. 


\author{
obrigações alienantes, nem imediatamente como «trabalho» $(\text { Arbeit })^{63}$
}

Ora, na perspectiva do Sollen, e por este ângulo ela há-de ser criticada, assistimos a uma decisiva inversão do sentido da referencialidade: «o objecto não existe mais para Mim, mas Eu existo para ele.» - «ist der Gegenstand nicht mehr für Mich, sondern Ich bin für ihn da.», STIRNER, EE, 2, II, 2; p. 326 -, consumando-se, nestes termos, um mesmo movimento de desapossamento e de alienação.

Marx e Engels são também decididos adversários do Sollen. No entanto, é porque assentam a sua crítica em fundamentos de outra natureza que podem afirmar, a propósito do registo (eticizante) em que a burguesia alemã «esclarecida» encarava as «formas» do «liberalismo político» que decorriam de um capitalismo desenvolvido: «Uma vez que as relações económicas alemãs, de longe, não tinham alcançado ainda o estádio de desenvolvimento ao qual essas formas políticas correspondiam, os cidadãos aceitavam essas formas apenas como ideias abstractas, princípios válidos em e para si, desejos e frases pios, autodeterminações kantianas da vontade e dos seres humanos, tal como eles devem ser.» - «Da die deutschen ökonomischen Verhältnisse noch bei weitem nicht die Entwicklungsstufe erreicht hatten, der diese politischen Formen entsprachen, so akzeptieren die Bürger diese Formen nur als abstrakte Ideen, an und für sich gültige Prinzipien, fromme Wünsche und Phrasen, Kantsche Selbstbestimmungen des Willens und der Menschen, wie sie sein sollen.», MARX - ENGELS, Die deutsche Ideologie. Kritik der neuesten deutschen Philosophie in ihren Repräsentanten Feuerbach, B. Bauer und Stirner, und des deutschen Sozialismus in seinen verschiedenen Propheten (1845-1846), III, 1, Altes Testament: Der Mensch, 6, A; MEW, vol. 3, p. 179.

${ }^{63}$ De acordo com a sua interpretação político-económica do capitalismo e do «socialismo» coevos, Stirner insurge-se contra as diferentes figurações principiais do «laboro, ergo sum» (cf. STIRNER, EE, 1, II, 3, § 3; p. 144, bem como Recensenten Stirners, KS, p. 357), pronunciando-se, em contrapartida, aparentemente a favor de um pretenso «trabalho livre»:

$« \mathrm{O}$ Estado repousa sobre a escravatura do trabalho. Se o trabalho for livre, o Estado perde-se.» - «Der Staat beruht auf der Sklaverei der Arbeit. Wird die Arbeit frei, so ist der Staat verloren.», STIRNER, EE, 1, II, 3, § 1; p. 127.

Comentando criticamente este enunciado, no sentido de lhe evidenciar as debilidades de fundamentação - e contextualizando-o no quadro histórico determinado de um aprofundamento da análise do trabalho assalariado em regime capitalista -, os autores de $A$ Ideologia Alemã, com uma visão certeira, chamam a atenção para uma afinal deficiente colocação do problema:

«O Estado moderno, a dominação da burguesia, repousa sobre a liberdade do trabalho. [...]. A liberdade do trabalho é a livre concorrência dos operários entre si. São Max [Stirner] tem muita infelicidade, tal como em todas as outras esferas, também na Economia Nacional. O trabalho é livre em todos os países civilizados; não se trata, portanto, de libertar o trabalho, mas de o superar [ou suprimir, aufheben, na sua forma assalariada].» - «Der moderne Staat, die Herrschaft der Bourgeoisie, beruht auf der Freiheit der Arbeit. [...]. Die Freiheit der Arbeit ist die freie Konkurrenz der Arbeiter unter sich. Sankt Max hat großes Unglück, wie in allen andern Sphären, so auch in der Nationalökonomie. Die Arbeit ist frei in allen zivilisierten Ländern; es handelt sich nicht darum, die Arbeit zu befreien, sondern sie aufzuheben.», MARX - ENGELS, Die deutsche Ideologie, III, 1, Altes Testament: Der Mensch, 6, A; MEW, vol. 3, p. 186. 
que tão-só denotaria uma camuflada persistência da servidão - a actividade autoconstituinte. Uma actividade compreendida como «um movimento e validação livres da pessoa ${ }^{64}$ ou de Mim» (eine freie Bewegung und Geltung der Person oder Meiner) ${ }^{65}$ - que num incessante fazer-se toma pé e desemboca: «Eu só sou Eu pelo facto de que $\mathrm{Eu} \mathrm{Me}$ faço, isto é, de que não [é] um Outro [que] Me faz, mas de que Eu tenho que ser a minha obra própria [mein eigen Werk].» ${ }^{66}$.

Não deparamos aqui, por conseguinte, apenas com a resolução do «ser» em «fazer» - destronando, em plena consonância, de resto, com as mundividências da «modernidade» empreendedora e do «individualismo possessivo», a detenção de uma «essencialidade» (morta) de predicados (como «propriedade» herdada) pela valorização de uma nova fonte de legitimidade em ascensão: a «obra», o «produto», o «adquirido».

É mais um passo que é dado, no sentido da radical «interiorização». A perspectiva que abre caminho é, sim, a de que - secundarizando, ou diluindo, a dimensão «aquisitiva» exterior, e excluindo terminantemente qualquer «alteridade» (lateral, ou superior) como origem da feitura - esse «fazer», em que o «ser» consiste, vem, eminente e primordialmente, a redundar num «fazer-se», num aconchegado movimento interno de auto-modelação.

No âmbito da nossa tradição filosófico-cultural, este programa de auto-engendramento ético-ontológico carrega decerto atrás de si e aos ombros - na multiplicidade (não raro, conflitual) das suas diversificadas determinações e coloraturas doutrinais - uma larga e imponente história.

Desde a longínqua Grécia, em que, bem antes de Sócrates e do seu programa de sondagem da interioridade ${ }^{67}$, já Heraclito dizia: «procurei-me

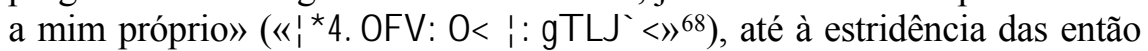

${ }^{64} \mathrm{O}$ «personalismo», concebido segundo o seu paradigma «egoísta», conta-se certamente entre as exigências de Stirner. Num artigo publicado na Rheinische Zeitung, em 1842, adianta-se já a reivindicação de um necessário projecto educativo centrado, não no «amestramento» (Dressur), mas na «auto-revelação» (Selbstoffenbarung) da «pessoa livre» (freie Person), em que a morte de uma submissão alienante aos ditames exteriores do «saber» (Wissen) se transfigure em ressurreição da «vontade» (Wille) própria. Cf. STIRNER, Das unwahre Princip unserer Erziehung, oder der Humanismus und Realismus (1842); KS, pp. 237-257.

${ }^{65}$ Cf. STIRNER, EE, 1, II, 3, § 1; p. 116.

66 «Ich bin nur dadurch Ich, daß Ich Mich mache, d. h. daß nicht ein Anderer Mich macht, sondern Ich mein eigen Werk sein muß.», STIRNER, EE, 2, II, 2; p. 256.

67 «Uma vida que não se perscruta não é, para o homem, vida que se possa viver» «"*• tes, 38 a.

${ }^{68}$ Cf. HERACLITO, Fragmento B 101; FVS, vol. I, p. 173. 
recentes formulações em que Fichte asseverava, a propósito do «agir» (Handeln), que «ele é assim, porque eu o faço assim» (es ist so, weil ich es so mache ${ }^{69}$, sem esquecer, obviamente, a atitude sage emblematicamente representada, nos tempos modernos, por Michel de Montaigne:

Seja eu o que for, quero sê-lo alhures [ailleurs] do que no papel. A minha arte e a minha indústria foram empregues em valorizar-me a mim mesmo [à me faire valoir moi-même $]^{70}$; os meus estudos [foram empregues] em ensinar-me a fazer [-me, $m$ 'apprendre à faire], não a escrever. Dediquei todos os meus esforços a formar a minha vida. Eis o meu ofício [métier], e a minha obra [ouvrage]. ${ }^{71}$

${ }^{69}$ Cf. FICHTE, Zweite Einleitung in die Wissenschaftslehre (1797), 4; SW, vol. I, p. 460.

${ }^{70}$ Curiosamente, «a autovalorização do Eu» (die Selbstverwertung des Ichs) assoma também no pensamento de Stirner como um imperativo, não apenas no âmbito de uma sua edificação interior, mas, muito em especial, no tabuleiro das suas confrontações com «o Estado» (der Staat) e com «a Sociedade» (die Gesellschaft). Cf. STIRNER, EE, 2, II, 2; pp. 303 e 353.

Bem mais «problemática» (para não carregar desagradavelmente na adjectivação) é, no entanto, a piedosa crença, em que as tiradas desta índole se alicerçam, de que esta «autovalorização» apregoada constitui o instrumento (subjectivo) que permite pôr fim (objectivamente?) à «pobreza» - e de que isso se leva a cabo «ascendendo na escala social»:

«O pauperismo só pode, então, ser eliminado quando Eu me valorizar como Eu, quando $\mathrm{Eu} \mathrm{Me}$ der valor a Mim próprio, e fizer eu próprio o meu preço. Eu tenho que me sublevar [empören] para subir [na vida, emporkommen].» - «Nur dann kann der Pauperismus gehoben werden, wenn Ich als Ich Mich verwerte, wenn Ich Mir selber Wert gebe, und meinen Preis selber mache. Ich muß Mich empören, um emporzukommen.», STIRNER, EE, 2, II, 2; p. 282.

Como Marx agudamente salienta, também aqui encontramos expressa «a trivial ilusão de burguês» (die triviale Bourgeoisillusion), em regra, contra outros dirigida, de acordo com a qual «cada um seria ele próprio culpado de não ter dinheiro nenhum» - «Jeder selbst schuld daran sei, wenn er kein Geld habe», MARX ENGELS, Die deutsche Ideologie, III, 1, Neues Testament: "Ich", 5, III, 3; MEW, vol. 3, p. 382.

Percebe-se, deste modo, sem dificuldades de maior, que não será inteiramente desprovida de razões a dura apreciação de que Stirner «tem o seu único mérito, contra a sua vontade e sem o saber: o mérito de ser a expressão dos pequenos burgueses alemães de hoje, que ambicionam tornar-se burgueses.» - «Sein einziges Ver[die]nst hat er wider seinen Willen und ohne es zu wissen: das Verdienst, der Ausdruck der deutschen Kleinbürger von heute zu sein, die danach trachten, Bourgeois zu werden.», MARX - ENGELS, Die deutsche Ideologie, III, 1, Neues Testament: "Ich", 5, III, 6, C; MEW, vol. 3, pp. 395-396.

71 «Quel que je sois, je le veux être ailleurs qu'en papier. Mon art et mon industrie ont été employés à me faire valoir moi-même; mes études, à m'apprendre à faire, 
Não nos deixemos, porém, seduzir - com precipitação de entusiasta, e sem cautelas de vigilância crítica - pelo traçado grandioso e pela tonalidade exigente de um prospecto (abstracto) de auto-construcção interior. No seu cerne, pulsam certamente as vibrações de um momento ético-antropológico de assunção da tarefa ontológica de conferir uma forma própria à condução do viver - e esta dimensão do «fazer-se» é, sem dúvida, ponderável e de reter. No entanto, quando o cuidado por esta plataforma subjectiva da «vivência» passa a ver-se transformado em preocupação exclusiva, ou primacial, numa cegueira inquebrantável relativamente a tudo o mais - pode muito bem acontecer que estejamos apenas a cair em episódicos acessos de um onirismo de compensação.

Não faltam, infelizmente, tanto nos arquivos do passado como nas derivas do presente, escapatórias defensistas e artificialismos edénicos que sabem «racionalizar» as suas diligências ou anseios nas mais elegantes e extremadas estetizações.

Se o «mundo» nos trata mal, nos é hostil e nos resiste - se, sobremaneira, não encontramos força para, na realidade, o combater e nele intervir -, então, parecem dizer-nos, tratemos de um sofisticado ajardinamento da nossa delicada intimidade, mesmo que a golpes de sonoras declamações contra os «fantasmas» (porventura, uma «espectrificação» de coisas bem reais) que imaginamos derribar a cada machadada de ideação.

Não é por acaso, nem por incontinência no alarde de erudição em literaturas estrangeiras, que os autores de Die deutsche Ideologie multiplicam - a propósito do pensamento de Stirner, e do que ele (re)presenta alusões a um dom-quixotismo de triste figura que, nas suas investidas cavalgantes, dramaticamente decerto, apenas acaba por dar às costas de uma «canonização [ou sacralização] do desespero» (Heiligsprechung der Heillosigkeit) ${ }^{72}$.

Vertida no molde, e segundo o maneirismo de Stirner, porém, a modelação interior desta feitura egocentrada não se limita a cuidar dos aspectos propriamente «positivos» que lhe conferem densidade e determinação. Não é a abertura festiva de uma triunfal marcha de auto-feitura do «Eu». Preparando e acompanhando a sua possibilidade de realização ${ }^{73}$ no

non pas à écrire. J'ai mis tous mes efforts à former ma vie. Voilà mon métier et mon ouvrage.», Michel de MONTAIGNE, Essais, II, 37; Oeuvres Complètes, ed. Robert Barral, Paris, Éditions du Seuil, 1967, p. 319.

72 Cf. MARX - ENGELS, Die deutsche Ideologie, Das Leipziger Konzil; MEW, vol. 3, p. 79.

${ }^{73}$ Recordemos que - no âmbito de uma recusa de recondução da «possibilidade» (Möglichkeit) à mera «pensabilidade» (Denkbarkeit), e de afirmação de que, no fundo, só é «possível» aquilo que cai dentro da esfera do meu «poder»-para Stirner: «Possibilidade e realidade coincidem sempre. Não se pode aquilo que não se faz, tal como não se faz nada que se não possa.» - «Möglichkeit und Wirklichkeit 
terreno «ideial» de que jamais se apartou, ela reveste-se igualmente de uma peculiar dialecticidade negacional, portadora de aspectos que merecem atenção.

\section{§ 5. Impulsos de «destruição»}

Em termos stirnerianos, na verdade, o almejado processo construtivo próprio - que se irá firmar na assunção própria da «ipseidade» de que se tem o senhorio (Eigenheit) ${ }^{74}$, e afirmar na conversão de tudo mais em objecto de «propriedade» (Eigentum) $)^{75}$ - tece-se e entretece-se também,

fallen immer zusammen. Man kann nichts, was man nicht tut, wie man nichts tut, was man nicht kann.», STIRNER, EE, 2, II, 3; p. 369.

${ }^{74}$ Nesta categoria stirneriana de Eigenheit - em que «toda a minha essência e existência» (mein ganzes Wesen und Dasein) é dita consistir -, a «ipseidade» do «próprio» (eigen) encontra-se dinamicamente sobredeterminada pela dimensão proprietária do «dono» (Eigner): «Eu sou livre [frei] de Aquilo de que estou solto [los], dono [Eigner] de aquilo que Eu tenho no meu poder [Macht] ou de aquilo de que sou poderoso [mächtig]. Eu sou propriamente Meu [Mein eigen], a todo o tempo e em todas as circunstâncias, quando Eu entendo que Me tenho e não me rebaixo ao Outro.» - «Frei bin Ich von Dem, was Ich los bin, Eigner von dem, was Ich in meiner Macht habe, oder dessen Ich mächtig bin. Mein eigen bin Ich jederzeit und unter allen Umständen, wenn Ich Mich zu haben verstehe und nicht an Andere wegwerfe.», STIRNER, EE, 2, I; p. 173.

75 A categoria «propriedade» (Eigentum) é empregue por Stirner para expressar - sob essa figura subjectiva da referência a «Mim» - a condição de toda alteridade, convertida em «objecto» de um «Eu» que dela como «proprietário» dispõe: «Eu tomo o mundo como aquilo que ele é para Mim, como [o domínio de] aquilo que é $\mathrm{Meu}$ [die Meinige], como propriedade Minha: Eu ligo tudo a Mim.» - «Ich nehme die Welt als das, was sie Mir ist, als die Meinige, als Mein Eigentum: Ich beziehe alles auf Mich.», STIRNER, EE, 1, I, 1, II; p. 14.

O comentário de Marx e de Engels, no que diz respeito à implicação onto-gnosiológica desta posição, é directo e cortante:

«No fundo, porém, ele não "toma o mundo", mas apenas a sua "fantasia febril" do mundo, como [sendo] a Sua, e apropria-Se dela. Ele toma o mundo como representação sua do mundo, e, como sua representação, o mundo é sua propriedade representada, a propriedade da sua representação, a sua representação como propriedade, a sua propriedade como representação, a sua representação peculiar, ou a sua representação da propriedade; e ele exprime tudo isto na incomparável proposição: "Eu ligo Tudo a Mim.".» - «Im Grunde "nimmt" er aber nicht "die Welt", sondern nur seine "Fieberphantasie" von der Welt als die Seinige und eignet sie Sich an. Er nimmt die Welt als seine Vorstellung von der Welt, und als seine Vorstellung ist die Welt sein vorgestelltes Eigentum, das Eigentum seiner Vorstellung, seine Vorstellung als Eigentum, sein Eigentum als Vorstellung, seine eigentümliche Vorstellung, oder seine Vorstellung vom Eigentum; und dies Alles drückt er in dem unvergleichlichen Satze aus: "Ich beziehe Alles auf Mich.”.», MARX - EN- 
articuladamente e a cada passo, de movimentos de «destruição» (Zerstörung) e de «aniquilamento» (Vernichtung).

Consideremos, brevemente, alguns dos tabuleiros em que eles se vêm a fenomenalizar.

Ao nível da compreensão ontológica - como já anteriormente tivemos ocasião de assinalar - é recusado ao «ser» qualquer estatuto imponente de independência objectiva. $\mathrm{O}$ mundo só é, na precisa medida em que em torno de «Mim» gravita. $\mathrm{O}$ «em si», tomado como «propriedade Minha», é nulificado pela completa dissolução da sua onticidade coisal no «para Mim» que, pelo seu «poder» ${ }^{76}$ efectivo, dele decide e o manipula.

$\mathrm{O}$ «ser» (Sein), despojado da materialidade própria que lhe assiste, converte-se, deste modo, na qualificação funcional pragmática que - ao sabor de uma intencionalidade, a cada momento, definida - subjectivamente lhe estableço: no «valor» (Wert), na «significação» (Bedeutung), no «sentido» (Sinn), que «Eu» instrumentalmente lhe estipulo, por exclusiva referência a «mim», na minha esfera comportamental ${ }^{77}$. E este afã reificante e utilista não se confina em exclusivo ao mundo objectivado das «coisas» inanimadas; estende-se e coisifica, de igual modo, na perspectiva e na medida do meu «serviço», o «próximo» $(\text { der Mitmensch })^{78}$.

GELS, Die deutsche Ideologie, III, 1, Altes Testament: Der Mensch, 1; MEW, vol. 3, p. 110.

Para uma crítica do jogo que Stirner introduz entre as noções de Eigentum e de Eigenheit, onde, nomeadamente, se abstrai por inteiro do facto de a «propriedade privada» (Privateigentum) capitalista envolver «comando» (Kommando) sobre «trabalho alheio» (fremde Arbeit), veja-se, por exemplo: MARX - ENGELS, Die deutsche Ideologie, III, 1, Altes Testament: Der Mensch, 6, B; MEW, vol. 3, pp. 211-212.

76 «A Minha propriedade, porém, não é nehuma coisa [Ding], pois esta tem uma existência independente de Mim; propriamente meu é apenas o meu poder [Gewalt].» - «Mein Eigentum ist aber kein Ding, da dieses eine von Mir unabhängige Existenz hat; mein eigen ist nur meine Gewalt.», STIRNER, EE, 2, II, 2; p. 307.

${ }^{77}$ Cf. STIRNER, EE, 2, II, 3; pp. 376 e 382.

78 Como redentor caminho apregoado pelo «egoísmo» - contra a resignada e menorizante espera pela benevolência caritativa das «autoridades» em que a «plebe» (Pöbel) se deixa enganar e enredar - Stirner, envergando o camuflado de um implacável avanço de ideias, proclama:

«Agarra, e toma, aquilo de que Tu precisas! Com isto está declarada a guerra de Todos contra Todos. Somente $E u$ [é que] determino acerca do que Eu quero ter.» «Greife zu und nimm, was Du brauchst! Damit ist der Krieg Aller gegen Alle erklärt. Ich allein bestimme darüber, was Ich haben will.», STIRNER, EE, 2, II, 2; p. 286.

E, defenestrando os amolecidos sentimentos de condoída comiseração pelos semelhantes, acrescenta, páginas adiante: 
Por isso, levada a cogitação às extremadas fronteiras do radicalismo, «Eu» é o único «sujeito», e o sujeito «único». Ele tem, deste modo, que ser desvendado como a «medida» $(M a \beta)$ de todas as coisas ${ }^{79}$ - em qualquer plano de consideração, e sob qualquer ângulo de abordagem - e, por consequência, tecnicamente, como o «critério» (Kriterium) da verdade ${ }^{80}$.

«Ninguém é para Mim uma pessoa de respeito [Respektsperson], o próximo [der Mitmensch] também não, mas [é], exclusivamente, tal como outros seres [Wesen], um objecto [Gegenstand], pelo qual Eu tenho, ou também não [tenho], compaixão [Teilnahme], um objecto interessante ou desinteressante, um sujeito que pode servir [brauchbar] ou sem préstimo [unbrauchbar].» - «Es ist Keiner für Mich eine Respektsperson, auch der Mitmensch nicht, sondern lediglich wie andere Wesen ein Gegenstand, für den Ich Teilnahme habe oder auch nicht, ein interessanter oder uninteressanter Gegenstand, ein brauchbares oder unbrauchbares Subjekt.», STIRNER, EE, 2, II, 2; p. 349.

Vale a pena recordar a descrição sucinta que Engels efectua da figura determinada de que esta «guerra de todos contra todos» pelo uso dos demais se revestia na vida corrente das grandes cidades inglesas, que acabara de visitar:

«Tal como o amigo Stirner, as pessoas encaram-se umas às outras apenas como sujeitos que podem servir [brauchbare Subjekte]; cada um explora os outros, e resulta daí que o mais forte espezinha o mais fraco, e que os poucos [que são] fortes, isto é, os capitalistas, se apoderam de $t u d o$, enquanto aos muitos [que são] fracos, aos pobres, mal resta a vida nua.» - «Wie Freund Stirner sehen die Leute einander nur für brauchbare Subjekte an; jeder beutet den andern aus, und es kommt dabei heraus, daß der Stärkere den Schwächeren unter die Füße tritt und daß die wenigen Starken, das heißt die Kapitalisten, alles an sich reißen, während den vielen Schwachen, den Armen, kaum das nackte Leben bleibt.», ENGELS, Die lage der arbeitenden Klasse in England. Nach eigner Anschauung und authentischen Quellen (1845), Die großen Städte; Mew, vol. 2, p. 257.

79 A famosa sentença de Protágoras, segundo a qual «o homem é a medida de todas as coisas: daquelas que são, tal como são; daquelas que não são, tal como não são»

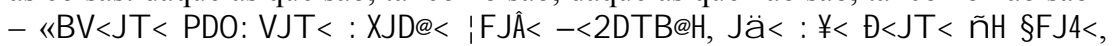

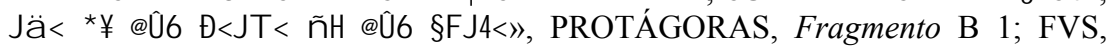
vol. II, p. 263 - tinha, desde logo, suscitado o problema da identificação do sujeito, e da instância, fundadores dessa mensura.

Tal como na Antiguidade, de resto, este princípio havia conhecido no quadro do idealismo alemão, em geral, e também por parte da Crítica jovem-hegeliana, diferentes interpretações de cunho e intenção comunitária ou «Humanista», valorizadoras da dimensão de uma racionalidade genérica.

É visando directamente todos os posicionamentos desta índole, e procurando romper com a persistência de quaisquer ambiguidades capturáveis por uma «transcendência» disfarçada, que Stirner se apressa a declarar «que não [é] o Ser Humano que é a medida de tudo, mas que Eu [sou] essa medida» - «daß nicht der Mensch das Maß von Allem, sondern daß Ich dieses Maß sei.», STIRNER, EE, 2, II, 3; p. 395.

80 «Eu sou o critério da verdade» - «Ich bin das Kriterium der Wahrheit», STIRNER, EE, 2, II, 3; p. 400. Alguns parágrafos atrás, por sua vez, deparamos com a emer- 
Ao nível representacional, o impulso destruidor que anima, desde o mais fundo, uma assumida «egoidade» absolutamente autocentrada ${ }^{81}$ senhora de si, e exercendo em plenitude a sua judicatura discricionária sem ter que observar quaisquer padrões de normatividade - ressoa estrondosamente pelas variadas e repetidas proclamações iconoclastas de uma impiedosa «dessacralização» (Entheiligung), que, ao seu redor, nem no Céu, nem na Terra, nem mesmo na interioridade das consciências alguma coisa deve poupar ${ }^{82}$.

Neste quadro, «o sagrado» (das Heilige) vem a corresponder à categoria em que pejorativamente se arrumam todas as outras categorias; isto é, todas as hipostasiações de conceitos abstractos («Deus», "Moral», «Humanidade», «Política» etc.) e todas as totalidades concretas («Igrejas», «Estado», «Sociedade», «Partido»), que constituem - enquanto «universalidade» (Allgemeinheit) e «vínculo» (Band), fundamentos da dimensão «comunitária» e da «obrigação» - «o inimigo irreconciliável» (der unversöhnliche Feind) da singularidade única, posto que configuram um necessário «entrave» (Fessel) que prende e atabafa o seu desabrochar livre $^{83}$.

gência clara de toda uma dimensão pragmática e decisionista: «A verdade é morta, uma letra, uma palavra, um material, que Eu posso usar [ou consumir, verbrauchen]. Toda a verdade para si é morta, um cadáver; ela só é viva do mesmo modo que o meu pulmão é vivo, a saber: na medida da minha vitalidade própria. As verdades são [um] material, como a erva boa ou a erva daninha; se erva boa ou erva daninha, a decisão acerca disso reside em Mim.» - «Die Wahrheit ist tot, ein Buchstabe, ein Wort, ein Material, das Ich verbrauchen kann. Alle Wahrheit für sich ist tot, ein Leichnam; lebendig ist sie nur in derselben Weise, wie meine Lunge lebendig ist, nämlich in dem Maße meiner eigenen Lebendigkeit. Die Wahrheiten sind Material wie Kraut und Unkraut; ob Kraut oder Unkraut, darüber liegt die Entscheidung in Mir.», STIRNER, EE, 2, II, 3; p. 398.

81 «Tudo gira em torno de Ti, Tu és o centro do mundo exterior e o centro do mundo dos pensamentos.» - «Um Dich dreht sich Alles, Du bist die Mitte der Aussenwelt und die Mitte der Gedankenwelt.», STIRNER, Recensenten Stirners (1845); KS, p. 354.

82 «O egoísta, ao virar-se contra as impressões e conceitos do presente, completa, sem misericórdia, a mais desmedida dessacralização. Nada para ele é sagrado!»«Indem der Egoist sich gegen die Anmutungen und Begriffe der Gegenwart wendet, vollzieht er unbarmherzig die maßloseste Entheiligung. Nichts ist ihm heilig!», STIRNER, EE, 2, II; p. 202.

83 Cf. STIRNER, EE, 2, II, 2; p. 237.

Desde as primeiras produções literárias publicadas, deparamos com esta magnificação do homem «que se sente a si próprio e não quer ser conduzido em andadeiras, quando sabe percorrer sozinho o seu caminho» - «der sich selbst fühlt und nicht gegängelt sein will, wenn er seinen Weg allein zu verfolgen weiß», STIRNER, Gegenwort eines Mitgliedes der Berliner Gemeinde wider die Schrift der sieben 
O «sagrado» a abater - nos termos de uma declamação em diversos registos proferida, e em múltiplos palcos encenada - vem a representar, por conseguinte, o domínio introjectado e feiticista (no fundo, venera-se nessas entificações uma «substancialização» resplandecente de que se ignora a feitura obscurecida) de todas as transcendências alienantes ${ }^{84}, \mathrm{o}$ desconforto de «Eu» me encontrar mergulhado num ambiente «estranho» que não é o da «minha casa» ${ }^{85}$, e onde, por consequência, são outros ou, de outrem, os poderes que imperam e me subjugam, inclusivamente, sob a pretensão afiançada, de que eles, afinal, são «meus» ${ }^{86}$.

Por sua vez, no plano imediato do viver mais prosaico - e com uma vincada implicação ideológica e política que não podia, de modo algum, passar despercebida, e incólume, aos círculos da «esquerda» hegeliana e

und fünfzig Berliner Geistlichen: Die christliche Sonntagsfeier, ein Wort der Liebe an unsere Gemeinen (1842); KS, p. 30.

Esta perspectiva volta a estar em evidência mais tarde, tendo por pano de fundo toda uma demarcação relativamente às ilusões da Gattungswesen de inspiração feuerbachiana, e uma celebração encomiástica do desgarramento solitário:

«Eu sou o meu género [Gattung], sou sem norma, sem lei, sem modelo e coisas semelhantes. É possível que, de Mim, eu possa fazer muito pouco; este pouco é, porém, tudo, e é melhor do que aquilo que Eu deixo fazer de Mim, pelo poder de outros, pelo amestramento do costume, da religião, das leis, do Estado, etc.» «Ich bin meine Gattung, bin ohne Norm, ohne Gesetz, ohne Muster u. dergl. Möglich, das Ich aus Mir sehr wenig machen kann; dies Wenige ist aber Alles und ist besser, als was Ich aus Mir machen lasse durch die Gewalt Anderer, durch die Dressur der Sitte, der Religion, der Gesetze, des Staates usw.», STIRNER, EE, 2, II; p. 200.

84 «O mundo que o crente ([o] espírito crente) cria chama-se Igreja; o mundo que o ser humano ([o] espírito humano ou humanitário) cria chama-se Estado. Isto, porém, não é mundo meu.» - «Die Welt, welche der Gläubige (gläubige Geist) schafft, heißt Kirche, die Welt, welche der Mensch (menschliche oder humane Geist) schafft, heißt Staat. Das ist aber nicht meine Welt.», STIRNER, EE, 2, II; p. 197.

85 «Estranheza [Fremdheit] é uma marca [distintiva] do "sagrado". Em todo o sagrado reside algo de "infamiliar" [Unheimliches], isto é, de estranho [Fremdes], pelo que nós não estamos totalmente à vontade [heimisch] e em casa. Aquilo que Me é sagrado não Me é próprio» - «Fremdheit ist ein Kennzeichen des "Heiligen". In allem Heiligen liegt etwas "Unheimliches", d. h. Fremdes, worin Wir nicht ganz heimisch und zu Hause sind. Was Mir heilig ist, das ist Mir nicht eigen», STIRNER, EE, 1, II, 2, § 2; p. 40.

${ }^{86}$ Cf., por exemplo, STIRNER, EE, 2, II, 2; pp. 246-247.

Vejam-se também as bem humoradas considerações críticas dirigidas contra as doutrinas que insistem em fazer do «sagrado» o «absolutamente interessante, que deve ser interessante sem o interessado» - «absolut Interessante, welches ohne den Interessenten interessant sein soll», STIRNER, Recensenten Stirners (1845); KS, p. 359 . 
do então nascente «comunismo filosófico» ${ }^{87}$-, a campanha de «destruição» proclamada alarga-se, e estende-se, sobrevoando o sempre requerido cuidado pelas discriminações de conteúdo ${ }^{88}$, a tudo o que simplesmente detenha, ou aspire a deter, estação na existência.

Lembremos uma passagem de Der Einzige und sein Eigentum que se me afigura particularmente esclarecedora:

A nova luta mundial está dirigida, como se diz, contra o "subsistente" [das Bestehende]. Costuma, todavia, entender-se isto mal [mißverstehen], como se apenas aquilo que agora subsiste devesse ser trocado por um outro subsistente melhor. Só que a guerra deveria antes ser declarada ao próprio subsistir [dem Bestehen selbst], isto é, ao estado [Staat] (status), não a um Estado determinado [bestimmter Staat], não porventura apenas ao estado [Zustand $]$ actual do Estado ${ }^{89}$.

${ }^{87}$ Penso que é a esta luz, designadamente, que se tem que entender, desde logo, um dos aspectos centrais da recensão crítica levada a cabo por Moses Hess:

«Stirner, sobretudo, não quer nada. Ele apenas fanfarrona. [...] Ele quer aniquilar continuamente o "Estado", e permanece continuamente no solo deste. Ele enaltece, em todas as tonalidades, o regresso ao mundo animal e, no fim, quer dizer apenas um vegetar pacifico.» - «Stirner will überhaupt Nichts. Er renommirt nur. [...]. Er will den "Staat" fortwährend vernichten und bleibt fortwährend auf dessen Boden stehen. Er preiset aus allen Tonarten die Rückkehr zur Thierwelt an und meint am Ende nur ein friedliches Vegetiren.», HESS, Die letzten Philosophen (1845); PSS, p. 392.

${ }^{88}$ Como, relativamente à atitude de Stirner - eivada de indiferença para com o teor determinado, e a significação concreta, dos diferentes «espectros» que invectiva -, Marx e Engels criticamente sublinham: «A hostilidade contra a Lei funciona apenas contra a forma, não contra o conteúdo. Qualquer lei repressiva, que o ameace com [o] patíbulo ou com [a] roda, está para ele totalmente correcta [ganz recht], desde que ele a possa captar [fassen] como uma declaração de guerra.» - «Die Feindschaft wider das Gesetz geht nur gegen die Form, nicht gegen den Inhalt. Jedes Repressivgesetz, das ihm mit Galgen und Rad droht, ist ihm ganz recht, insofern er es als eine Kriegserklärung fassen kann.», MARX - ENGELS, Die deutsche Ideologie, III, 1, Neues Testament: “Ich”, 5, A, II; MEW, p. 315.

89 «Der heurige Weltkampf ist, wie man sagt, gegen das "Bestehende" gerichtet. Man pflegt dies jedoch so zu mißverstehen, als sollte nur, was jetzt besteht, mir anderem, besserem Bestehenden vertauscht werden. Allein der Krieg dürfte vielmehr dem Bestehen selbst erklärt sein, d. h. dem Staate (status), nicht einem bestimmten Staate, nicht etwa nur dem derzeitigen Zustande des Staates», STIRNER, EE, 2, II, 2; p. 246.

Não é de excluir que Marx seja, nesta passagem, o directamente visado. Efectivamente, numa carta a Ruge de 1843 - que viria a ser publicada, em 1844, nos Deutsch-französische Jahrbücher (cf. Ein Briefwechsel von 1843; $\mathrm{MEGA}^{2}$, vol. I/2, p. 487) -, Marx coloca como tarefa central do movimento «a crítica sem contemplações de todo o subsistente» - «die rücksichtslose Kritik alles Bestehenden», MARX, Brief an Arnold Ruge, September 1843; MEGA², vol. III/1, p. 55. 
A consequência, de alguma maneira esperada, é o delineamento e montagem de uma vistosa cruzada - a pretexto de uma pregada e estrénua radicalização sem compromissos ${ }^{90}$ conduzida -, que não deixa de assumir contornos e destinatários curiosos.

Com efeito, esta incursão vibrante não tem em conta, nem investe contra, as condições determinadas que moldam (para todos) e afligem (no que toca à maioria) o viver dos humanos, mas, pelo contrário, toma por alvo directo os movimentos «revolucionários» (porventura, deficientemente conhecidos na sua diversidade doutrinal e prática, mas convenientemente taxados em bloco de «reformistas ${ }^{91}$ ), que, assim se alega, apenas visariam substituir (e por que não: transformar?) um «estado de coisas» dado (subsistente) por uma outra «construcção» (Aufbau) institucional ${ }^{92}$ (entrevista

Stirner conhecia o Zur Judenfrage de Marx - saído no número dessa mesma revista -, que cita (cf. STIRNER, EE, 2, II; p. 192), e que, pelo menos em comparação com os textos de Moses Hess, apreciara (cf. STIRNER, Recensenten Stirners; KS, pp. 389-390).

90 Sintomaticamente - e sobre o fundo de uma interpretação exclusiva da «mediação» como pusilânime concordantismo «conciliador» - é recorrente a colocação de problemas nos termos disjuntivos de um «ou...ou», tanto na forma de «aut...aut» (STIRNER, EE, 2, II, 1; p. 218), como na de «entweder...oder» (STIRNER, EE, 2, II, 2; p. 242).

91 Stirner tende, efectivamente, a amalgamar estas duas orientações políticas, já na altura bem diferenciadas, sob um mesmo guarda-chuva, resumindo os propósitos que as animavam na expeditiva sentença de que se trataria tão-só da ilusão de pretender introduzir «melhoramentos, onde nada mais há a melhorar» - «Verbesserungen, wo nichts mehr zu verbessern ist», STIRNER, Die Mysterien von Paris von Eugène Sue (1844); KS, p. 295.

Não é, pois, sem fundamento que Marx e Engels, identificando as fontes em que Stirner se baseia, criticam as fortes debilidades por ele reveladas no que diz respeito a uma informação fidedigna sobre estes movimentos no seu tempo, e sobre as suas lutas. Cf. MARX- ENGELS, Die deutsche Ideologie, III; MEW, vol. 3, por exemplo, pp. 191 e 305.

92 Como, aliás, era corrente em todo o período do Vormärz, o tema da «revolução» não podia deixar de começar por ser introduzido, na Alemanha, senão a partir de alguma interpretação dos acontecimentos ocorridos em França:

«A revolução não estava dirigida contra o subsistente, mas contra este subsistente, contra uma estabilidade [Bestand] determinada. Ela aboliu este dominador [Herrscher], não $o$ dominador; pelo contrário, os franceses foram dominados do modo mais inexorável [...]. Até aos dias de hoje, o princípio de revolução [das Revolutionsprinzip] ficou-se por lutar apenas contra este ou aquele subsistente, isto é, por ser reformatório. Por mais melhoradamente, por mais fortemente que o "progresso prudente" possa ser observado: apenas é sempre posto um senhor novo no lugar do antigo, e o derrubamento é uma construcção.» -

«Die Revolution war nicht gegen das Bestehende gerichtet, sondern gegen dieses Bestehende, gegen einen bestimmten Bestand. Sie schaffte diesen Herrscher ab, nicht den Herrscher, im Gegenteil wurden die Franzosen aufs unerbittlichste 
como «melhor», mas igualmente destinada à «subsistência»).

A justificação do ponto de vista eleito para a condução da campanha - que se desprende, e depreende, de aquilo que por Stirner é aduzido parece convergir para o reconhecimento de que a grande exigência visceral que a «singularidade única» a si mesma se coloca é, tão-só, a de uma persistente e inconformada «sublevação» (Empörung), anti- ou meta-política, pela edificação de uma inquieta interioridade «egoísta».

A citação é longa, mas condensa, porventura, os traços centrais do posicionamento de Stirner:

Revolução e sublevação [Empörung] não podem [dürfen] ser encaradas como sinónimas. Aquela consiste num revolucionamento [Umwälzung] das situações [Zustände], da situação subsistente ou status, do Estado ou da Sociedade: é, por isso, um acto político ou social; esta tem decerto por consequência inevitável uma transformação [Umwandlung] das situações, porém, não parte delas, mas da insatisfação [Unzufrienheit] dos seres humanos consigo [mit sich]: não é um levantamento [de desagrado das hostes contra os chefes, eine Schilderhebung], mas um levantamento do singular [eine Erhebung der Einzelnen], um subir [na vida, ou na escala social, Emporkommen], sem tomar em consideração as organizações [Einrichtungen] que daí brotam. A revolução apontava para organizações novas, a sublevação conduz-Nos a não nos deixarmos mais organizar, mas a organizarmo-nos a Nós próprios, e não põe nas "instituições" [Institutionen] qualquer esperança resplandecente. Ela não é nenhuma luta contra o subsistente, pois, quando ela se dá, o subsistente desmorona-se por si próprio; ela é apenas um desenvencilhar [Herausarbeiten] de Mim relativamente ao subsistente. ${ }^{93}$

beherrscht [...]. Bis auf den heutigen Tag ist das Revolutionsprinzip dabei geblieben, nur gegen dieses und jenes Bestehende anzukämpfen, d. h. reformatorisch zu sein. So viel auch verbessert, so stark auch der "besonnene Fortschritt" eingehalten werden mag: immer wird nur ein neuer Herr an die Stelle des alten gesetzt, und der Umsturz ist ein Aufbau.», STIRNER, EE, 1, II, 3, §1; p. 121.

93 «Revolution und Empörung dürfen nicht für gleichbedeutend angesehen werden. Jene besteht in einer Umwälzung der Zustände, des bestehenden Zustandes oder status, des Staats oder der Gesellschaft, ist mithin eine politische oder soziale Tat; diese hat zwar eine Umwandlung der Zustände zur unvermeidlichen Folge, geht aber nicht von ihr, sondern von der Unzufriedenheit der Menschen mit sich aus, ist nicht eine Schilderhebung, sondern eine Erhebung der Einzelnen, ein Emporkommen, ohne Rücksicht auf die Einrichtungen, welche daraus entsprießen. Die Revolution zielte auf neue Einrichtungen, die Empörung führt dahin, Uns nicht mehr einrichten zu lassen, sondern Uns selbst einzurichten, und setzt auf "Institutionen" keine glänzende Hoffnung. Sie ist kein Kampf gegen das Bestehende, da, wenn sie gedeiht, das Bestehende von selbst zusammenstürzt, sie ist nur ein Herausarbeiten Meiner aus dem Bestehenden.», STIRNER, EE, 2, II, 2; p. 354.

Também no que a estas matérias diz respeito os comentários de Marx e de Engels não almofadam a contundência: 


\section{§ 6. A leveza da nadificação}

Tenhamos, no entanto, presente que, na economia do pensamento de Stirner, a convocação deste «impulso destruidor» não se leva a cabo apenas para efeitos de liminar desembaraçamento e limpeza do terreno circundante especularmente apreendido.

Verifica-se, de igual modo, a emergência nítida de uma certa «dialéctica negacional» que tem que se voltar também para as paragens da própria intimidade, que não há-de permanecer intocada.

Trata-se, a bem dizer, de uma perspectiva com que desde cedo deparamos em Stirner, nomeadamente, quando, na recensão que dedica a Die Posaune des jüngsten Gerichts (1841) de Bruno Bauer, publicada no Telegraph für Deutschland de Hamburgo em Janeiro do ano seguinte, cuida de salientar aí «a vocação histórico-mundial do radicalismo» (der weltgeschichtliche Beruf des Radikalismus) como emblema luzente de um comportamento em que o seu protagonista não se limita a «destruir» tudo aquilo que na envolvência externa obstaculiza o seu desabrochar próprio, mas se «destrói» também a si mesmo ${ }^{94}$, no sentido de que tem a coragem e a lucidez de continuamente não se deixar «coisificar».

Daí a celebração encomiástica de uma peculiar «permanência da impermanência» que, na constante criatividade a cada momento renovada, caracteriza «os caracteres eternos, nos quais a firmeza [die Festigkeit] consiste apenas na incessante maré cheia da sua autocriação hora a hora [stündliche Selbstschöpfung], e que, por isso, são eternos, porque se fazem eles próprios a cada instante a temporalidade [Zeitlichkeit] do seu fenómeno de cada vez [jedesmalige Erscheinung], a partir da frescura,

«A unidade de sentimentalidade e de fanfarronice é a sublevação [Empörung]. Na sua orientação para fora, contra outros, ela é fanfarronice; na sua orientação para dentro, como resmungar-em-si, ela é sentimentalidade. Ela é a expressão específica da má-vontade impotente do filisteu.» - «Die Einheit von Sentimentalität und Renommage ist die Empörung. In ihrer Richtung nach Außen, gegen Andre, ist sie Sentimentalität; in ihrer Richtung nach innen, als Knurren-in-sich, ist sie Sentimentalität. Sie ist der spezifische Ausdruck des ohnmächtigen Widerwillens des Philisters.» -, e, claro está, como se trata do derrubamento de «fantasmas», e como «para ele, o mundo real de modo algum subsiste» (die wirkliche Welt für ihn gar nicht besteht), pode tranquilamente «continuar também a subsistir» (auch fortbestehen)... Cf. MARX - ENGELS, Die deutsche Ideologie, III, 1, Neues Testament: "Ich", 3; MEW, vol. 3, respectivamente, pp. 281 e 282.

94 «ele não deita somente abaixo o mundo subsistente para ele próprio permanecer; ele deita-se abaixo ele próprio.» - «er stürzt nicht allein die bestehende Welt, um selber stehen zu bleiben; er stürzt sich selbst.», STIRNER, Über B. Bauer's Posaune des jüngsten Gerichts (1842); KS, p. 19. 
que nunca murcha nem envelhece, e da actividade de criação, do seu espírito eterno» ${ }^{95}$.

É, pois, esta «nadificação» de amarras e de pressupostos que funda, em última instância, aquela auto-posição na existência, em contínuo re-instalada, como apropriação perpetuamente fresca de uma «ingenuidade» jamais perdida ou hipotecada, que constitui a marca, e o mais «próprio», da egoidade que no singular se declina.

Como neste mesmo artigo de 1842 para a Rheinische Zeitung se refere ainda:

A própria verdade não consiste em nada de outro senão no revelar [Offenbaren] de si próprio, e a isso pertence o achar [Auffinden] de si próprio, a libertação relativamente a todo o estranho [Befreiung von allem Fremden], a abstracção [Abstraktion] mais extrema ou a isenção [Entledigung] relativamente a toda a autoridade [Autorität], a ingenuidade [Naivetät $]$ reganhada. ${ }^{96}$

É, de facto, neste quadro, e nesta atmosfera, de inquietação lábil, a cada passo recomeçada, e pronta a saltar, que ganha, por conseguinte, a sua inteligibilidade cabal todo um conjunto de teses sobre o qual a predilecção de Max Stirner acentuadamente recai.

À preocupação angustiada por viver a qualquer preço, tal como à ocupação afadigada e exclusiva com aquilo a que no viver quotidiano das sociedades é reconhecido preço, urge contrapôr o prospecto de uma (tão vulgarmente desconsiderada) "fruição do viver» (Lebensgenu $\beta$ ). Fruir a vida, porém, confessa-nos Stirner, convoca desgaste, ou «destruição» parcial de si por um uso: é consumir-se no preciso acto de envolvimento com ela ${ }^{97}$.

95 «Die ewigen Charaktere, in welchen die Festigkeit nur in dem unablässigen Fluthen ihrer stündlichen Selbstschöpfung besteht, und die darum ewig sind, weil sie sich in jedem Augenblicke selbst machen, weil sie die Zeitlichkeit ihrer jedesmaligen Erscheinung aus der nie welkenden und alternden Frische und Schöpfungsthätigkeit ihres ewigen Geistes setzen», STIRNER, Das unwahre Princip unserer Erziehung, oder der Humanismus und Realismus (1842); KS, p. 253.

96 «Die Wahrheit selbst besteht in nichts Anderem, als in dem Offenbaren seiner selbst, und dazu gehört das Auffinden seiner selbst, die Befreiung von allem Fremden, die äusserste Abstraktion oder Entledigung von aller Autorität, die wiedergewonnene Naivetät.», STIRNER, Das unwahre Princip unserer Erziehung, oder der Humanismus und Realismus (1842); KS, p. 249.

97 «Quem apenas está preocupado com [o facto de] que viva esquece facilmente, nessa ansiedade, a fruição da vida. [...]. Mas, como [é que] se tira proveito [nutzen] da vida? Gastando-a, de igual modo como a vela, de que se tira proveito queimando-a. Tira-se proveito da vida, e portanto de si, o vivo, consumindo-a e [consumindo-]se. Fruição de vida é gasto da vida.» - «Wer nur besorgt ist, daß er 
E aqui, uma vez mais, voltamos a enfrentar uma peculiar dialéctica (íntima) de afirmação e de «aniquilamento». Fruir é «consumir-se», fundamentalmente, porque «que $\mathrm{Eu}$ me consumo significa apenas que $\mathrm{Eu}$ sou. Eu não me pressuponho [voraussetzen], porque Eu só me ponho [setzen], ou crio [schaffen], a cada instante, em geral, e só por esse facto $\mathrm{Eu}$ sou, porque Eu não sou pressuposto, mas posto, e, de novo, posto apenas no momento em que Me ponho, isto é, $\mathrm{Eu}$ sou, em um, criador e criatura. ${ }^{98}$.

Como vimos, «Eu» é a condição radicante de qualquer pensar e de qualquer agir; todavia, esta instância de egoidade - «liberta» de peias para se autodeterminar, mais do que «livre» por alguma outorga de estatuto ${ }^{99}$ - não se encontra ela própria, segundo Stirner, sobredeterminada na sua imanência por nenhum «poder» (externo ou interno) que sobre ela se exerça, no sentido de a vincular a alguma direcção pré-definida, ou de, em qualquer caso, a limitar principialmente no seu campo de actuação.

lebe, vergißt über diese Ängstlichkeit leicht den Genu $\beta$ des Lebens. [...]. Wie aber nutzt man das Leben? Indem man's verbraucht, gleich dem Licht, das man nutzt, indem man's verbrennt. Man nutzt das Leben und mithin sich, den Lebendigen, indem man es und sich verzehrt. Lebensgenu $\beta$ ist Verbrauch des Lebens.», STIRNER, EE, 2, II, 3; pp. 358-359.

98 «daß Ich Mich verzehre, heißt nur, daß Ich bin. Ich setze Mich nicht voraus, weil Ich Mich jeden Augenblick überhaupt erst setze oder schaffe, und nur dadurch Ich bin, daß Ich nicht vorausgesetzt, sondern gesetzt bin, und wiederum nur in dem Moment gesetzt, wo Ich Mich setze, d. h. Ich bin Schöpfer und Geschöpf in Einem.», STIRNER, EE, 1, II, 3, § 3; p. 167.

Como Marx e Engels agudamente observam: «Segundo a sua teoria, a sua vontade de hoje tem antes que ser a denegação [Verneinung] da sua [vontade] de ontem, porque ele tem a obrigação [Verpflichtung] de, como criador, se comportar para com a sua vontade de ontem dissolvendo-a. Só enquanto "desprovido de vontade" [pré-determinada, Willenloser] ele é criador; como realmente querente [als wirklich Wollender], ele é sempre criatura.» - «Nach seiner Theorie $m u \beta$ vielmehr sein heutiger Wille die Verneinung seines gestrigen sein, weil er die Verpflichtung hat, sich als Schöpfer auflösend zu seinem gestrigen Willen zu verhalten. Nur als "Willenloser" ist er Schöpfer, als wirklich Wollender ist er stets Geschöpf.», MARX - ENGELS, Die deutsche Ideologie, III, 1, Neues Testament: “Ich”, 5, A, II; MEW, vol. 3, p. 315.

99 É porque entende fundamentalmente a «liberdade» como um «libertar-se de» todos os fantasmas que a assombram, no sentido de lhe conferir um «conteúdo» (Inhalt) - de que originariamente se encontra desprovida - próprio, que Stirner pode afirmar que «a liberdade dada (outorgada) não é contudo liberdade nenhuma, uma vez que só a liberdade que se toma, portanto, a liberdade do egoísta, navega a todo o pano.» - «die gegebene (oktroyierte) Freiheit doch keine Freiheit ist, da nur die Freiheit, die man sich nimmt, also die Freiheit des Egoisten, mit vollen Segeln schifft.», STIRNER, EE, 2, I; p. 185. 
Por isso se não deixam de verberar todos os programas de instauração de uma «moralidade racional» (remotamente de extracção kantiana, hegeliana, ou liberal) ou de uma civilidade (romântica e reaccionária) religiosamente nostálgica, mas também fundada sobre o pilar das convicções «interiores».

Perseguindo por caminhos diversos uma mesma finalidade de «cristianização do povo» (Christianisierung des Volkes) ${ }^{100}$, em clave laica ou eclesial, eles vêm, no fundo, a irmanar-se e a convergir num reforço disfarçado das dominações (persistentes) pelo afeiçoamento (eticamente assistido) de uma «autonomia» ficcionada:

A "autoactividade ética" [sittliche Selbsttätigkeit] corresponde totalmente à "filosofia religiosa e ortodoxa", à "monarquia constitucional", ao "Estado cristão", à "liberdade dentro de certas limitações", à "liberdade de imprensa limitada", ou, numa imagem, ao herói acorrentado à cama de doente ${ }^{101}$.

É esta radical ausência de pressupostos, mesmo na esfera da interioridade mais íntima, que leva a singularidade egóica (que detenha o completo senhorio de si) a jamais se encontrar coarctada por considerações de universalidade abstracta (que a funcionalizem a alguma ideia transcendente de «Humanidade») ${ }^{102}$, ou por ditames de «racionalidade» (cuja observância devenha imperativa) ${ }^{103}$; a poder corporizar a mais pura discricionariedade do «arbítrio» (Willkür) ${ }^{104}$ eximida a qualquer servilismo reverente, e a poder «divertir-se» (sich amüsieren), numa inocência despreocupada, seguindo tão-só as inclinações de um «gosto» (Geschmack) ${ }^{105}$ próprio; a determinar-se, em suma, como perfeita «irreflexão» (Gedankenlosigkeit) desprendida de quaisquer preconceitos - uma vez que a nenhum «pensamento» feito, ou «fixo», se subordina ${ }^{106}$ : «O pensamento só Me é próprio,

100 Cf. STIRNER, EE, 2, II, 2; p. 248.

101 «Die "sittliche Selbsttätigkeit" entspricht ganz der "religiösen und rechtgläubigen Philosophie", der "konstitutionellen Monarchie", dem "christlichen Staate", der "Freiheit in gewissen Schranken", der "beschränkten Preßfreiheit", oder in einem Bilde dem ans Krankenlager gefesselten Helden.», STIRNER, EE, 1, II, 2, § 3; p. 76.

102 «Aquilo que se atribuiu à ideia da Humanidade pertence-Me.» - «Was man der Idee der Menschheit zuschrieb, das gehört Mir.», STIRNER, EE, 2, II, 3; p. 367.

103 «Que Eu Me faça "audível”, somente isso é "razão”, por muito irracional que Eu seja» - «Daß Ich Mich "vernehmbar" mache, das allein ist "Vernunft", sei Ich auch noch so unvernünftig», STIRNER, EE, 2, II, 3; p. 388.

104 Cf. STIRNER, EE, 2, II, 3; p. 377.

105 Cf. STIRNER, EE, 2, II, 3; p. 396.

106 «só a irreflexão me salva realmente perante os pensamentos» - «nur die Gedan- 
quando Eu não hesito [kein Bedenken tragen], a cada momento, a pô-lo em perigo de vida [Todesgefahr], quando Eu não tenho a temer a sua perda [Verlust] como uma perda para Mim, [como] uma perda de Mim. O pensamento só é então propriamente meu quando Eu decerto o posso subjugar, mas jamais ele a Mim, [quando ele] nunca Me fanatiza e faz [de mim] instrumento da sua realização.» ${ }^{107}$, ou como páginas adiante se acrescenta: «só através desta irreflexão [Gedankenlosigkeit], desta menosprezada "liberdade de pensamento" [Gedankenfreiheit] ou liberdade relativamente ao pensamento [Freiheit vom Gedanken], Tu és propriamente teu.» ${ }^{108}$

\section{§ 7. Não «o que», mas «quem» é o sujeito}

Considerando retrospectivamente a trajectória filosófica que até então efectuara, Fichte assinalava que esse percurso se encontrava, de alguma maneira, comandado pela questão de saber «o que [was] eu próprio sou, e o que é [was ist] a minha destinação [Bestimmung]» ${ }^{109}$.

Apesar de todas as aparentes semelhanças - e de todos os efectivos pontos de contacto (não só ao nível das formulações, mas também no que toca ao inicial ponto de visão enformador) - entre as respectivas doutrinas, a interrogação reitora que preside ao pensamento amadurecido de

kenlosigkeit rettet Mich wirklich vor den Gedanken», STIRNER, EE, 1, II, 3, § 3; p. 164.

Esta «irreflexão», assim recuperada, pode inclusivamente revestir o viso minimalista da interjeição aclamativa - «um jubiloso hurra» (ein aufjauchzendes Juchhe), como nesta mesma página se refere -, a qual, como mais tarde será explicado, é susceptível de representar «a forma simples da crítica egoísta» («die einfache Form der egoistischen Kritik», STIRNER, Recensenten Stirners (1845); KS, p. 364.

Em termos de intertextualidade, recordemos que também o poema de Goethe de que no início se fez menção, a propósito da fórmula «fiz de Nada a minha causa», se encontra regularmente pontuado por este «hurra» (Juchhe) exclamativo. Cf. GOETHE, «Vanitas! vanitatum vanitas!» (1806), Geselliger Lieder (1815); WW, vol. 1, pp. 132-133.

107 «Eigen ist Mir der Gedanke erst, wenn Ich ihn jeden Augenblick in Todesgefahr $\mathrm{zu}$ bringen kein Bedenken trage, wenn Ich seinen Verlust nicht als einen Verlust für Mich, einen Verlust Meiner, zu fürchten habe. Mein eigen ist der Gedanke erst dann, wenn Ich zwar ihn, er aber niemals Mich unterjochen kann, nie Mich fanatisiert, zum Werkzeug seiner Realisation macht.», STIRNER, EE, 2, II, 3; pp. 384-385.

108 «nur durch diese Gedankenlosigkeit, diese verkannte "Gedankenfreiheit" oder Freiheit vom Gedanken bist Du dein eigen.», STIRNER, EE, 2, II, 3; p. 389.

109 «was bin ich selbst, und was ist meine Bestimmung?», FICHTE, Die Bestimmung des Menschen (1800), I; SW, vol. II, p. 169. 
Max Stirner releva, não obstante, de um matiz distinto, que se tornará decisivo, e do qual, aliás, ele manifesta plena consciência.

Quando fala de «Eu» - e muito em especial, quando pretende desvendá-lo como «o único» (der Einzige) ${ }^{110}$-, Stirner não se propõe levar a cabo uma indagação «essencial» (cujo resultado seria, platonicamente, a definição de uma «entidade» ou @i $F \backslash$ ", como resposta à pergunta: «o que é x?»), nem tão-só assentar uma constatação «existencial»: o facto de que (aristotelicamente, "J 4 ) a instância egóica «é», nem mesmo, axiologicamente, reservar para ela um estatuto privilegiado de «particularidade» ou de «especialidade» que (por favor, graça, merecimento, ou conquista) a distinguisse relativamente aos demais entes com os quais comungasse à partida a horizontalidade de uma mesma condição ${ }^{111}$.

Stirner pretende, sim, e de um modo fundamental, pôr em evidência, na sua unicidade, a nudez impositiva ${ }^{112}$ do sujeito - in-determinado, no duplo sentido de que não recebe de fora a sua determinação, e de que, interiormente, é a cada momento que se auto-determina, em exclusivo, a partir de si -, ao qual tudo o mais tem que passar a ver-se referido.

À tese stirneriana de que «o ser humano singular, somente, é $o$ ser humano» (der einzelne Mensch allein ist der Mensch) ${ }^{113}$, de que «Eu, este Único, sou o ser humano» (Ich, dieser Einzige, bin der Mensch) ${ }^{114}$, subjaz uma fundamental mudança de perspectiva quanto ao que verdadeiramente importa apurar: a questão não é fixar o conteúdo (entitativo ou essencial) desse «Único», mas identificá-lo como a fonte manante, original e originariamente renovada, de todos os conteúdos possíveis.

110 Procurando, uma vez mais, assinalar a sua demarcação relativamente a Fichte, Stirner dirá que não tem em vista «o Eu» (das Ich) - partilhado, numa esfera de exterioridade, por «cada um» (Jeder) numa comunidade genérica de pertença -, mas a singularidade única: «Eu não sou, porém, um Eu ao lado de outros Eus, mas o Eu exclusivo [das alleinige Ich]: Eu sou único.» - «Ich bin aber nicht ein Ich neben andern Ichen, sondern das alleinige Ich: Ich bin einzig.», STIRNER, EE, 2, II; p. 406.

111 «Eu não Me tenho por algo de particular [ou de especial], mas por único.» - «Ich halte Mich nicht für etwas Besonderes, sondern für einzig.», STIRNER, EE, 1, II, $3, \S 3 ;$ p. 153.

112 É, sem dúvida, com uma ironia mordaz, mas também com flagrante oportunidade, que Marx, a propósito destes enfunamentos do «Único», evoca, em português, versos de Os Lusíadas: "Cesse tudo o que a Musa antiga canta,/ Que outro valor mais alto se alevanta.» (Luís de CAMÕES, Os Lusíadas, I, 3, 7-8). Cf. MARX ENGELS, Die deutsche Ideologie, III, 1, Neues Testament: "Ich", 6; MEW, vol. 3, p. 413.

113 Cf. STIRNER, EE, 1, II, 3, § 1; p. 121.

114 Cf. STIRNER, EE, 2, III; p. 411. 
Mas, uma vez aqui chegados, é de novo - e compreensivelmente, tendo em conta a bateria de supostos que abastecem esta teorização, e que se encontra a ser manejada - o discurso chão do radical despojamento que volta a insinuar-se.

Como na réplica a diferentes críticas que lhe haviam sido dirigidas, não sem ironia, se explicita:

O Único é um enunciado [Aussage], do qual, com toda a franqueza e honestidade, se admite que ele Nada [Nichts] enuncia. O Ser Humano, o Espírito, o verdadeiro Indivíduo, a Personalidade, etc., são enunciados ou predicados que regorgitam de uma abundância do conteúdo, frases com suprema riqueza de pensamentos; o Único, frente a essas frases sagradas e sublimes [heilige und erhabene Phrasen], é a frase vazia [die leere Phrase], despretenciosa, e totalmente comum ${ }^{115}$.

O «Único» é, na realidade, mais do que um nada de enunciação, a enunciação do «Nada». Por conseguinte, não há lugar a um apuramento daquilo em que ele substancialmente consista, mas, sim e tão-só, à chamada de atenção para a instância de subjectividade própria em que ele in-siste, e que urge tomar a cargo no sentido de a «actualizar».

Relativamente ao «Eu», assim recortado das suas representações triviais, não se trata, portanto, e como intenção primordial, de estabelecer «aquilo que ele é» (das, was er ist), mas de tomar activamente posse de «aquele que ele é» (der, der er ist $)^{116}$.

$\mathrm{Ou}$, como em Der Einzige und sein Eigentum, acentuando o deslocamento da maneira de interrogar, no mesmo sentido se refere:

A pergunta por conceito [Begriffsfrage]: "o que [was] é o ser humano?" transpôs-se, então, para a [pergunta] pessoal [persönliche Frage]: "quem [wer] é o ser humano?". Com "o que" [was], procurava-se o conceito, para o realizar; com [o] "quem" [wer], não há mais pergunta nenhuma, mas a resposta está também pessoalmente disponível no perguntador: a pergunta responde-se por si própria [von selbst $]^{117}$.

115 «Der Einzige ist eine Aussage, von welcher mit aller Offenheit und Ehrlichkeit eingeräumt wird, dass sie Nichts aussagt. Der Mensch, der Geist, das wahre Individuum, die Persönlichkeit u. s. f. sind Aussagen oder Prädicate, welche von einer Fülle des Inhalts strotzen, Phrasen mit höchsten Gedankenreichtum; der Einzige ist, gegenüber jenen heiligen und erhabenen Phrasen, die leere, anspruchslose und ganz gemeine Phrase.», STIRNER, Recensenten Stirners (1845); KS, p. 347.

116 Cf. STIRNER, Recensenten Stirners (1845); KS, p. 349.

117 «Die Begriffsfrage: “was ist der Mensch?” hat sich dann in die persönliche umgesetzt: "wer ist der Mensch?". Bei "was" suchte man den Begriff, um ihn zu 
A pergunta pelo «quem», ou por «aquele que», des-cobre o perguntador na imediatez práxica do seu ser de respondente - e nele prontamente se apaga, posto que o «conteúdo» que ele detém não é mais do que o seu próprio «acto». Aquele por que na interrogação se pergunta é, ele próprio, no e pelo viver que protagoniza - e que, a montante e a juzante, aberto de determinações se encontra - o respondimento que se busca.

$\mathrm{O}$ «Único» não tem, com efeito, que saber de antemão «aquilo que é» (essencialmente) para em conformidade com esse cabedal teórico erigido em padrão, ou norma, cujo estatuto é de natureza apenas «fantasmática» - consciencializar a sua «missão» e orientar os seus comportamentos; o «Único» tem simplesmente que ser: que se exercer, ou que se «exer-ser», realizando-se na e pela existência que, a cada momento, diante de si se abre no preciso momento em que ele pisa a cena.

Mais do que horizonte futuro a preencher ${ }^{118}$ (o que representaria ainda uma condescendência mascarada para com as figuras «espectrais» de um "Além»), esta existência coincide com o preenchimento efectivo de um espaço presente - na solidão majestática (que se reclama, e a que se faz reclame) da uni-potência, no desamparo (que se não lamenta) de qualquer princípio norteador, na irrepetibilidade de todo o gesto (que jamais funda um património, mas apenas põe em movimento, e ao seu serviço, «propriedades» de distintos contornos): «Tudo em Mim é único.» - tanto na ordem sincrónica das coisas, como segundo o vector diacrónico do devir - «E, só como este Eu Único, Eu tomo [sobre mim] apropriar-Me de Tudo, enquanto apenas como esse [Eu Único] Me activo e desenvolvo [...]. Eu desenvolvo-Me como Eu. Este é o sentido do Único.» ${ }^{119}$.

Nada mais sou do que aquilo que, no e pelo meu desenvolvimento, faço, isto é, do que aquilo que - respaldado na minha «ipseidade» (Eingenheit), e com a minha «propriedade» (Eigentum) - de mim faço, como manifestação radical de expressividade. Mas aí, apenas o senhorio do «dono» (Eigner) assoma: nada do que nesse fazer(-me) faço se me pega ou incorpora como densidade determinada que (historicamente) me coisificasse.

realisieren; bei “wer” ist's überhaupt keine Frage mehr, sondern die Antwort im Fragenden gleich persönlich vorhanden: die Frage beantwortet sich von selbst.», STIRNER, EE, 2, III; pp. 411-412.

118 Para Stirner, o «porvir» faz parte integrante daquela ganga de «transcendências», que as mais variadas «sacralidades» - de figurino societal, humanitário, político, religioso, ou moral - tratam de consagrar, convertendo o «Eu» num projecto continuamente adiado... «para o futuro» (in der Zukunft). Cf. STIRNER, EE, 2, II, 2; p. 247.

119 «Alles an Mir ist einzig. Und nur als dieses einzige Ich nehme Ich Mir Alles zu eigen, wie Ich nur als dieses Mich betätige und entwickle [...]. [...] als Ich entwickle Ich Mich. Dies ist der Sinn des Einzigen.», STIRNER, EE, 2, II; p. 406. 
Não causa, por tudo isto, admiração inesperada que esta «des-coisificação» ciente e desejada, que a nadificação - a radical ausência de determinações, que somente a cada instante, actuando e actuando-se, se dá conteúdo - se venha a consumar, desta feita, em inefabilidade. (Tal como tradicionalmente acontece com o «Nada» místico, aliás).

Em rigor - desprovido de qualquer teor antecipado que se adiante além da mera dinâmica identitativa do «Eu» -, o «Único», naquilo que em si mesmo seja, é, afinal e realmente, «o indenominável» (das Unnennbare $)^{120}$. Porque não partilha nem participa de uma universalidade (o abstracto «espectral») que lhe seja ontológica ou axiologicamente superior: «nem Eu, nem Tu, somos dizíveis [sagbar], Nós somos inexprimíveis, porque só [os] pensamentos são dizíveis e no dizer subsistem.» ${ }^{121}$. Ou porque, de acordo com uma outra formulação posterior: «Tu, Impensável e Inexprimível, és o conteúdo das frases, o dono das frases, a frase em pessoa [die leibhaftige Phrase], Tu és o Quem [Wer], o Aquele [Der] da frase.» ${ }^{122}$ - de uma frase que nunca está pronunciada antes de ser feita.

Atendendo a que nunca está de antemão dito, nem substancialmente vinculado ao que alguma vez disse, só o quem que enuncia - conta. Aquilo que enuncia corresponde à «irreflexão» do momento, e só importa como atestação da «vontade» e do "poder» que nele, e por ele, se firma.

$\mathrm{O}$ «Único» responde ${ }^{123}$, na medida em que se vai «gastando» ou

120 Cf. STIRNER, EE, 1, II, 3, § 3; p. 164.

121 «weder Ich noch Du sind sagbar, Wir sind unaussprechlich, weil nur Gedanken sagbar sind und im Sagen bestehen.», STIRNER, EE, 2, II, 2; p. 348.

122 «Du, Undenkbarer und Unaussprechlicher, bist der Phraseninhalt, der Phraseneigner, die leibhaftige Phrase, Du bist der Wer, der Der der Phrase.», STIRNER, Recensenten Stirners (1845); KS, p. 350.

123 Poderá parecer estranho, ou até infundado, que, a propósito desta visão «actualista» e «accionalista» de Stirner, se fale de «resposta», uma vez que esta pressupõe a diferencialidade, ou a heterogeneidade, de um «estímulo», como condição (ou condicionamento) da «re-acção» (não forçosamente «reactiva» ou mecânica) em que consiste.

De um modo sintomático, o aspecto fulcral da questão, num marco idealista, aparecia já no tratamento fichteano do tema do «embate» ou do «choque» $($ Ansto $\beta)$ que, à primeira vista, obrigaria o «Eu» a reconhecer praticamente, como resistencialidade, a co-existência de alguma materialidade.

Fichte perspectiva o problema, cuidando de que assim se esfumariam quaisquer veleidades ontológicas do «dogmatismo» materialista, pelo lado em que, sublinha ele, só há «choque» (Anstoß), na precisa medida em que «a sua possibilidade é condicionada pela actividade do Eu» - «seine Möglichkeit durch die Thätigkeit des Ich bedingt wird», FICHTE, Grundlage der gesammten Wissenschaftslehre (1794), II, § 4, E, III; SW, vol. I, p. 212.

Curiosamente, a abordagem de Stirner a esta matéria vem a explorar o mesmo filão: «As forças deixam-se decerto aguçar e multiplicar, particularmente, por re- 
«desgastando», mas não é, em rigor, responsável - porque não tem contas a prestar nem a outrem (acima, ou ao lado, dele), nem a ele próprio (dentro dele); tem apenas que ser, e que, in-submisso ou em "sublevação», usar e usar-se nessa consumação, revestida de consumição.

O contexto próximo é, certamente, o de uma justificada crítica dos empolamentos retóricos e «bem-intencionados», próprios das grandes liturgias filantrópico-morais do «Homem»e da «Humanidade» ${ }^{124}$. No entanto, a imaginosa invocação do «mundo animal» remete-nos para uma bem mais seca e desencantada conformação:

Nenhuma ovelha, nenhum cão, se dá ao trabalho [sich bemühen] de se tornar uma "ovelha recta [recht], um cão recto"; a nenhum animal a essência dele aparece como uma tarefa [Aufgabe], isto é, como um conceito que ele tenha para realizar. Ele realiza-se, tirando partido da vida [sich ausleben], isto é, dissolvendo-se, dissipando-se. Ele não anseia por ser, ou por se tornar, algo de diferente [etwas Anderes] do que aquilo que é ${ }^{125}$.

sistência hostil ou por assistência amiga; mas onde se dá pela falta da sua aplicação, aí pode estar-se certo também da sua ausência. Pode-se golpear [schlagen] fogo de uma pedra, mas, sem o golpe [Schlag], nenhum [fogo] sai [dela]; de igual maneira, também o ser humano precisa do "choque" [Ansto $\beta]$.»- «Die Kräfte lassen sich allerdings schärfen und vervielfältigen, besonders durch feindlichen Widerstand oder befreundeten Beistand; aber wo man ihre Anwendung vermißt, da kann man auch ihrer Abwesenheit gewiß sein. Man kann aus einem Steine Feuer schlagen, aber ohne den Schlag kommt keines heraus; in gleicher Art bedarf auch ein Mensch des “Anstoßes”.», STIRNER, EE, 2, II, 3; pp. 366-367.

124 «O filantropismo é um amor celestial, espiritual, um [amor] padresco. [...]. Quem se exalta por $o$ Ser Humano deixa, na medida em que aquela exaltação [visionária, Schwärmerei] se estende, as pessoas fora de atenção, e flutua num interesse ideal, sagrado. Sim, $o$ Ser Humano não é pessoa nenhuma, mas um ideal, um fantasma.» - «Der Philanthropismus ist eine himmlische, geistige, eine pfäffische Liebe. [...]. Wer für den Menschen schwärmt, der läßt, soweit jene Schwärmerei sich erstreckt, die Personen außer Acht und schwimmt in einem idealen, heiligen Interesse. Der Mensch ist ja keine Person, sondern ein Ideal, ein Spuk.», STIRNER, EE, 1, II, 3, § 3; p. 85.

125 «Kein Schaf, kein Hund bemüht sich, ein "rechtes Schaf, ein rechter Hund” zu werden; keinem Tier erscheint sein Wesen als eine Aufgabe, d. h. als ein Begriff, den es zu realisieren habe. Es realisiert sich, indem es sich auslebt, d. h. auflöst, vergeht. Er verlangt nicht, etwas Anderes zu sein oder zu werden, als es ist.», STIRNER, EE, 2, II, 3; p. 372.

Curiosamente, embora num endereço doutrinal acentuadamente diferente (a que não falta o aceno para uma dimensão afectiva do «ser»), encontramos formulações (e um ponto de vista para a crítica de uma hipostasiação da «essência») muito semelhantes em Feuerbach:

«O ser [Sein] não é nenhum conceito universal, despegável das coisas. Ele faz um com aquilo que é. [...]. O ser é a posição [Position] da essência [Wesen]. Aquilo 
que [é] a minha essência é o meu ser. O peixe é na água, mas deste ser tu não podes despegar a sua essência. [...]. Só onde [está] o teu coração, aí tu estás. Porém - excepto nos casos contra natura [naturwidrig] -, todas as coisas estão contentes de estar onde estão e estão contentes [de ser] aquilo que são, isto é, a sua essência não está despegada do seu ser, o seu ser não [está despegado] da [sua] essência.» - «Das Sein ist kein allgemeiner, von den Dingen abtrennbarer Begriff. Es ist eins mit dem, was ist. [...]. Das Sein ist die Position des Wesens. Was mein Wesen, ist mein Sein. Der Fisch ist im Wasser, von diesem Sein kannst du nicht sein Wesen abtrennen. [...]. Nur wo dein Herz, da bist du. Aber alle Dingen sind - naturwidrige Fälle ausgenommen - gerne da, wo, und gerne das, was sie sind, d. h., ihr Wesen ist nicht von ihrem Sein, ihr Sein nicht vom Wesen abgetrennt.», FEUERBACH, Grundsätze der Philosophie der Zukunft (1843), § 27; GW, vol. 9, pp. 306-307.

Em passagens desta índole, tanto Feuerbach como Stirner pretendem remover a Wesen de um estatuto transcendente de essencialidade abstracta - e, eventualmente, de «dever-ser» (Sollen) detentor de conotações morais kantianizantes -, identificando-a, pelo contrário, com a imediatez de aquilo que na esfera da «sensibilidade» (Sinnlichkeit) objectivamente se dá.

No entanto, por deficiência de compreensão ontológica - que não tem na devida conta nem a dialecticidade constitutiva do real, nem o papel que a prática (social, mas também individual) no seu âmbito desempenha -, estas concepções acabam por instalar uma redução da realidade do ser ao existente, que consagra (porventura, de um modo não em toda a sua implicação subjectivamente deliberado) a ordem (factual) estabelecida.

Daí, o severo comentário crítico de Engels, num apontamento que só já no século $\mathrm{XX}$ viria a ser publicado, a propósito do citado passo de Feuerbach - mas que, em rigor, abrange e atinge todos os posicionamentos que a partir de supostos análogos se perfilam e adiantam:

«Um lindo elogio do subsistente [Bestehende]. Exceptuando os casos contra natura, poucos, [exceptuando] os casos anormais, estás contente com o porteiro de sete anos de uma mina de carvão, catorze horas sozinho no escuro, e isto porque, como o teu ser [é assim], também assim é a tua essência.» - «Eine schöne Lobrede auf das Bestehende. Naturwidrige Fälle, wenige, abnorme Fälle ausgenommen, bist Du gerne mit dem siebenten Jahre Türschließer in einer Kohlengrube, vierzehn Stunden allein im Dunkeln, und weil Dein Sein, so ist es auch Dein Wesen.», ENGELS, Feuerbach; MEW, vol. 3, p. 543.

Do ponto de vista marxista, a indispensável crítica do Sollen como fundamento (moral) de uma intervenção transformadora nas realidades representa apenas uma vertente da desmistificação de todas aquelas doutrinações, muito espalhadas, que, directa ou remotamente, assentam «nesta crença filosófica no poder criador mundano, e destruidor mundano, dos conceitos» - «in diesem philosophischen Glauben an die weltschöpferische und weltzerstörende Macht der Begriffe», MARX - ENGELS, Die deutsche Ideologie, Der wahre Sozialismus, I, A; MEW, vol. 3, p. 455.

Em termos histórico-materiais e dialécticos, a «essência», na sua realidade, não se define abstractamente como uma «universalidade» eternizada, nem se reconduz ao mero reforço de uma positividade empírica imediata:

«a essência humana não é nenhum abstracto [Abstraktum] inerente ao indivíduo singular. Na sua realidade [efectiva, Wirklichkeit], ela é o conjunto [das ensemble] 
Na verdade - porque, como em Die deutsche Ideologie se não deixa de assinalar a propósito do «Único» de Stirner, «toda a sua actividade [Tätigkeit] e todo o seu comportamento [Verhalten] para com o mundo é uma mera aparência [Schein]» ${ }^{126}$-, também esta afinal conformada acomodação com o existente se pode vir a revelar como um prosaico campo de aterragem do «ego-ísmo».

das relações sociais.» - «das menschliche Wesen ist kein dem einzelnen Individuum inwohnendes Abstraktum. In seiner Wirklichkeit ist es das ensemble der gesellschaftlichen Verhältnisse.», MARX, Thesen über Feuerbach, 6; MEW, vol. 3, p. 6. Isto é, a «essência», enraízada materialmente num viver concreto, é um horizonte de possibilidades reais de que à prática - individual e social - cumpre cuidar (inclusivamente, num desígnio de reconfiguração) e conferir materialidade de realização.

Como Moses Hess, fazendo-se eco de todas estas perspectivas que iam sendo elaboradas no círculo que em torno de Marx se organizava - e impregando-as já de uma peculiar coloratura feuerbachiana (que haveria de se acentuar no seu desenvolvimento posterior em direcção ao socialismo «verdadeiro»), não isenta de «algumas patranhas idealistas» (einige idealistische Flausen) carregadas de pregação do «amor do próximo» (Menschenliebe, cf. ENGELS, Brief an Marx, 19. November 1844; MEGA $^{2}$, vol. III/1, p. 255) - explicita:

«O idealismo subjectivo não tornou o ser humano essencialmente livre, mas [apenas] livre da sua essência. A essência do ser humano é o "ser genérico" [Gattungswesen], como Feuerbach algo misticamente se expressa, é o operar conjunto [Zusammenwirken] dos indivíduos, como nós mais aproximadamente temos que o determinar. Enquanto este operar conjunto, tanto no mundo espiritual como no [mundo] material, no pensar como no agir, não existir ainda; enquanto os seres humanos não virem que, só reunidos, podem viver como seres humanos, e, de acordo com isso, realmente agir; enquanto eles, pelo contrário, continuarem a viver, e a operar, separados uns dos outros: a vida deles não é essencialmente humana [human], mas essencialmente egotista [selbstisch], animal.» - «Der subjektive Idealismus hat den Menschen nicht wesentlich frei, sondern frei von seinem Wesen gemacht. Das Wesen des Menschen ist das "Gattungswesen", wie Feuerbach sich etwas mystisch ausdrückt, es ist das Zusammenwirken der Individuen, wie wir dies näher bestimmen müssen. So lange dieses Zusammenwirken, in der geistigen sowohl, wie in der materiellen Welt, im Denken, wie im Handeln, noch nicht existirt; so lange die Menschen nicht einsehen, daß sie nur vereint als Menschen leben können, und wirklich danach handeln; so lange sie im Gegentheil noch immer getrennt von einander leben und wirken, ist ihr Leben nicht wesentlich human, sondern wesentlich selbstisch, thierisch.», HESS, Über die sozialistische Bewegung in Deutschland (1845), 1; PSS, p. 287.

126 «seine ganze Tätigkeit und sein ganzes Verhalten zur Welt ein bloßer Schein ist», MARX - ENGELS, Die deutsche Ideologie, III, Neues Testament: "Ich", 2; MEW, vol. 3, p. 249. 


\section{§. Momento ético subjectivo}

Em Barmen, Friedrich Engels estava certamente a emitir um juízo precipitado quando, em Novembro de 1844, transmitindo a Marx (que se encontrava ainda em Paris) as suas primeiras opiniões acerca da leitura de Der Einzige und sein Eigentum (de que Otto Wigand lhe havia enviado as folhas de impressão), imaginava - embalado, talvez, por alguns vibrantes acordes libertários de Stirner acerca da «associação de egoístas» (Verein von Egoisten) que haveria de «aniquilar» (vernichten) a «Sociedade» reinante ${ }^{127}$ - que bastaria um certo reviramento, uma Umkehrung, para o incorporar (embora criticamente, e releborado) aos cabedais teóricos da luta que, juntamente com o amigo, havia começado a desenvolver:

127 Cf. STIRNER, EE, 2, II; p. 96. «A dissolução da Sociedade, porém, é o comércio [Verkehr] ou associação [Verein]. [...]. Há uma diferença entre se [é] a minha liberdade, ou a minha ipseidade [Eigenheit], [que] é limitada por uma sociedade. Se o caso fôr aquele, ela é uma congregação [Vereinigung], um convénio, uma associação; se, porém, a ruína ameaça a ipseidade, ela é um poder para si, um poder sobre Mim, algo de a Mim inacessível, que Eu, decerto, posso olhar com espanto [anstaunen], adorar, reverenciar, respeitar, mas não dominar e dissipar, e não o posso, decerto, porque $\mathrm{Eu}$ [me] resigno.» - «Die Auflösung der Gesellschaft aber ist der Verkehr oder Verein. [...]. Es ist ein Unterschied, ob durch eine Gesellschaft meine Freiheit oder meine Eigenheit beschränkt wird. Ist nur jenes der Fall, so ist sie eine Vereinigung, ein Übereinkommen, ein Verein; droht aber der Eigenheit Untergang, so ist sie eine Macht für sie, eine Macht über Mir, ein von Mir Unerreichbares, das Ich zwar anstaunen, anbeten, verehren, respektieren, aber nicht bewältigen und verzehren kann, und zwar deshalb nicht kann, weil Ich resigniere.», STIRNER, EE, 2, II, 2; pp. 342 e 343-344.

Decorrido muito pouco tempo, e por razões que adiante se explicitam, o efectivo juízo de Engels acerca desta Verein de Stirner conhecerá uma perspectivação bem mais substanciada, nomeadamente, à luz da própria ambivalência que preside à representação burguesa liberal do Estado:

«A livre concorrência não quer nenhuma limitação, nenhuma fiscalização pelo Estado, o Estado todo é para ela um fardo, ela seria a mais perfeita [possível] numa situação totalmente desprovida de Estado em que cada um pode explorar os outros à vontade, como, por exemplo, na "associação" [Verein] do amigo Stirner. Uma vez que a burguesia, porém, desde logo para manter sob freio o proletariado que lhe é igualmente preciso, não pode passar sem o Estado, volta-o contra aquele [o proletariado] e procura mantê-lo [ao Estado] tanto quanto possível afastado dela.» - «Die freie Konkurrenz will keine Beschränkung, keine Staatsaufsicht, der ganze Staat ist ihr zur Last, sie wäre als vollkommensten in einem ganz staatlosen Zustand, wo jeder den andern nach Herzenlust ausbeuten kann, wie z. B. in Freund Stirners "Verein". Da die Bourgeoisie aber den Staat, schon um das ihr ebenso nötige Proletariat im Zaum zu halten, nicht entbehren kann, so wendet sie ihn gegen dies und sucht ihn sich soweit wie möglich entfernt zu halten.», ENGELS, Die Lage der arbeitenden Klasse in England (1845), Die Stellung der Bourgeoisie zum Proletariat; MEW, vol. 2, p. 488. 
Este egoísmo é levado tão ao extremo [so auf die Spitze getrieben], tão doido [toll] e, simultaneamente, tão consciente de si [ou autoconsciente, selbstbewußt], que, na sua unilateralidade [Einseitigkeit], não se pode aguentar um instante [sequer], mas tem logo que se converter [umschlagen] em comunismo ${ }^{128}$.

Estas ilusões - designadamente, no que se refere ao entendimento do «comunismo» que Stirner, abundantemente, patenteia ${ }^{129}$ - devem ter sido

128 «Dieser Egoismus ist so auf die Spitze getrieben, so toll und zugleich so selbstbewußt, daß er in seiner Einseitigkeit sich nicht einen Augenblick halten kann, sondern gleich in Communismus umschlagen muß.», ENGELS, Brief an Marx, 19. November 1844; MEGA $^{2}$, vol. III/1, p. 252.

129 Quanto às limitações da compreensão stirneriana do «comunismo», bastará recordar esta saborosa amostra, em que, cursivamente, se pretende assentar de uma penada a refutação da «universalidade» de que se reclama: «O comunismo, ao proclamar o bem de todos, aniquila directamente o bem-estar de aqueles que até então viviam das suas rendas e que, por isso, provavelmente, se encontravam melhor do que com a perspectiva das apertadas horas de trabalho [Arbeitsstunden] de Weitling.» - «Indem der Kommunismus das Wohl Aller proklamiere, vernichtet er gerade das Wohlsein derer, welcher seither von ihren Renten lebten und sich dabei wahrscheinlich wohler befanden, als bei der Aussicht auf die strengenden Arbeitsstunden Weitlings.», STIRNER, EE, 2, II, 2; p. 346.

Os comentários sarcásticos de Marx - que, designadamente, obrigam a que não se consinta na identificação mistificadora imediata da «esfera da individualidade» com aquilo que é decorrência da posição que se detém no âmbito geral de uma classe - vieram a ser bem conhecidos:

«E, finalmente, ele [Stirner] coloca aos comunistas a exigência moral de que se deviam, para toda a eternidade, deixar tranquilamente explorar pelos que vivem de rendas [Rentiers], negociantes, industriais, etc., porque eles não podem suprimir [aufheben] essa exploração sem, simultaneamente, aniquilarem o "bem-estar" desses senhores! [...]. O "bem-estar" de que aquele que vive de rendas [Rentier] goza, como aquele que vive de rendas, não é o "bem-estar" do indivíduo, como tal, mas o bem-estar de aquele que vive de rendas: [não é] nenhum [bem-estar] individual, mas um bem-estar universal no interior da classe [dos que vivem de rendas].» - «Und schließ[lich] stellt an die Kommunisten [die] moralische Zumutung, sie sollen sich von den Rentiers, Kaufleute, Industriellen etc. in alle Ewigkeit ruhig exploitieren lassen, weil sie diese Exploitation nicht aufheben können, ohne zugleich das "Wohlsein" dieser Herren zu vernichten! [...] Das "Wohlsein", das der Rentier als Rentier genießt, ist nicht das "Wohlsein" des Individuums als solchen, sondern das des Rentiers, kein individuelles, sondern ein innerhalb der Klasse allgemeines Wohlsein.», MARX - ENGELS, Die deutsche Ideologie, III, Altes Testament: Der Mensch, 6, B; MEW, vol. 3, p. 200.

Relativamente à referência de Stirner às «horas de trabalho», recorde-se que, para Wilhelm Weitling, no quadro do seu idealizante projecto de organização «comunista» da Sociedade, «a determinação de um tempo de trabalho para todos os que são capazes de trabalho» (die Bestimmung einer Arbeitszeit für jeden Arbeitsfähigen) torna-se «necessária» (notwendig) para a «manutenção de todos» (Erhaltung Aller), 
prontamente dissipadas por Marx assim que leu Der Einzige und sein Eigentum, e comunicadas numa carta que, entretanto, não chegou até nós. Conhecemos apenas a reacção de Engels: «No que diz respeito ao Stirner, estou inteiramente de acordo contigo. Quando eu te escrevi estava ainda demasiado enrredado [befangen] sob a impressão imediata do livro; desde que o deixei pousado e pude meditar sobre ele, acho o mesmo que tu achas.» ${ }^{130}$. Quanto ao alcance e ao conteúdo das críticas, é manifesto que eles começariam a encontrar o seu desenvolvimento mais determinado, pouco tempo volvido, já em Bruxelas, no labor conjunto que no manuscrito de Die deutsche Ideologie se depositou.

passando, assim, as «horas de trabalho» (Arbeitsstunden) a constituir a medida do «valor» (Wert) de todos os produtos e dos materiais requeridos para a sua fabricação. Cf. Wilhelm WEITLING, Garantien der Harmonie und Freiheit (1842), II, 10; ed. Ahlrich Meyer, Stuttgart, Philipp Reclam jun., 1974, pp. 163-164.

Para uma apreciação genérica do mérito das contribuições de Weitling, no quadro de uma embrionária formulação de ideias comunistas de extracção «operária», veja-se, por exemplo: MARX, Kritische Randglossen zu dem Artikel: "Der König von Preu \$en und die Socialreform. Von einem Preußen” (1844) e também Brief an Arnold Ruge, September 1843; $\mathrm{MEGA}^{2}$, respectivamente, vol. I/2, p. 459 , e vol. III/1, p. $55>$.

130 «Was den Stirner betrifft so bin ich durchaus mit Dir einverstanden. Als ich Dir schrieb war ich noch zu sehr unter dem unmittelbaren Eindruck des Buchs befangen, seitdem ich es hab liegen lassen und mehr durchdenken können, find ich dasselbe was Du findest.», ENGELS, Brief an Marx, 20. Januar 1845; $\mathrm{MEGA}^{2}$, vol. III/1, p. 259.

Num artigo publicado em The New Moral World, and Gazette of the Rational Society de Londres, em Maio de 1845, Engels manifesta já uma nítida consciência do significado, em termos de luta ideológica, dos pensamentos, não apenas de Bruno Bauer, mas também de Stirner, que aí são expressamente referidos como «os representantes das consequências últimas da filosofia alemã abstracta e, por conseguinte, os únicos opositores filosóficos importantes do Socialismo, ou antes: do Comunismo, uma vez que neste país a palavra Socialismo não significa senão as diferentes imaginações vagas, indefinidas e indefiníveis, de aqueles que vêem que alguma coisa tem que ser feita e, no entanto, não conseguem decidir-se a percorrer o caminho todo [the whole length] do sistema da Comunidade.» - «the representatives of the ultimate consequences of abstract German philosophy, and therefore the only important philosophical opponents of Socialism - or rather Communism, as in this country the word Socialism means nothing but the different vague, undefined and undefinable imaginations of those who see that something must be done, and who yet cannot make up their minds to go the whole length of the Community system.», ENGELS, Rapid Progress of Communism in Germany (1844-1845), III; MARX - ENGELS, Collected Works, ed. Jack Cohen, Maurice Cornforth, Maurice Dobb, E. J. Hobsbawm e outros, Moscow, Progress Publishers, 1975, vol. 4, p. 241. Penso que se trata de uma perspectiva fundamental para o entendimento do que tanto por Die heilige Familie, como por Die deutsche Ideologie, era visado, e se pretendia alcançar. 
No entanto, importa não esquecer que - apesar dos complacentes ardores destilados de uma impressão primeira (a que agradáveis recordações da anterior convivência berlinense no grupo dos Freien não teriam sido de todo alheias) - Engels pode igualmente, de caminho, ter surpreendido uma articulação central, que, porventura, e numa leitura benigna (que alguns não deixarão de taxar de benevolente), fornece a chave de acesso ao que de mais fundo Stirner havia, porventura, pretendido comunicar:

«E verdadeiro é decerto aí isto: que nós temos, primeiro, que nos apropriar [eignen] de uma causa [Sache] como [causa] nossa, que a tornar [uma] causa egoísta [egoistische Sache], antes de podermos fazer alguma coisa por ela» ${ }^{131}$.

De facto, Max Stirner - embora, à sua maneira, e enfunando-a numa teorização geral recheada de desmesurada unilateralidade delirante, mitificadora de fundamentos e mistificadora dos comportamentos - faz emergir e aponta, não obstante, para a dimensão da experiência radical de uma demanda de assunção subjectiva do viver.

Trata-se, na verdade, de uma plataforma vivencial que, certamente a partir de outros supostos materiais, e articulada como horizonte de uma concreção histórica em desenvolvimento, tem que ser compreendida - e que ser compreendida de uma maneira bem diferente. No entanto, não é, em rigor, de modo algum, legítimo, ou possível, descartar liminarmente essa dimensão, na medida em que corresponde a um "registo» e a uma «tonalidade» que, do interior, acompanha (e, sob muitos aspectos, perspectiva) o empreender determinado dos nossos compromissos vitais.

$\mathrm{Na}$ obra de Stirner em apreço, e no seu pensamento, em geral, apesar de todas as torções e devaneios, não estamos apenas perante o grito irrequieto ou lancinante de uma individualidade oprimida por peias societais (económicas, políticas, religiosas, culturais) - mais pressentidas do que verdadeiramente penetradas na sua natureza e dinâmica -, que a golpes de virtuosidade especulativa se procuram exorcismar.

Deparamo-nos, igualmente, aí, ainda que sob traços estetizados que lhe distorcem o viso, com um intento de trazer à luz aquilo que poderíamos designar por: momento ético subjectivo - aquela espessura íntima da subjectividade, em que ninguém pensa por mim, age por mim, sente (alegria e dor) por mim.

Contrariamente ao que parece acreditar a generalidade das representações hegemónicas - e, com os seus pregões amplificados, espalha, para

131 «Und wahr ist daran allerdings das, daß wir erst eine Sache zu unsrer eignen, egoistische Sache machen müssen, ehe wir etwas dafür thun können», ENGELS, Brief an Marx, 19. November 1844; MEGA², vol. III/1, p. 252. 
efeitos de consabida formatação ideológica das colectividades -, o materialismo não encara a «subjectividade» como um tabu ou como um tema obsceno a evitar, como uma renitência encaroçada a diluir em caldos de gregarismo, como um inimigo a abater.

Para o «materialismo prático» (a expressão encontra eco também em Die deutsche Ideologie) - que, na unidade de um mesmo movimento de demanda, procura reunir compreensão e revolucionamento dos «estados de coisas» encontrados e imperantes ${ }^{132}$-, o problema é outro, e tem outro contorno de estabelecimento.

No que diz respeito a esta dimensão ideológica particular dos processos histórico-sociais, aquilo que está em causa é, sim, uma atitude firme de frontalidade na confrontação crítica com concepções que - directamente, ou com mais rebuscamento de sofisticação, por razões que, no entanto, nunca relevam de uma «pura teoria» abstracta - erigem o «indivíduo» e a instância do «sujeito» (recortados e desligados da concreção deveniente do seu embasamento, envolvências, e dinâmica) em portátil e expeditiva arma de arremesso contra um programa consistente, e consequente, de intervenção prática material na transformação das realidades em processo de que os humanos constituem ingrediência e agência de mediação.

Daí, entre outras coisas, o persistente desafio que se estende (e que, em rigor, jamais deixou de ser colocado) a uma efectiva compreensão materialista da subjectividade - não apenas por razões circunstanciais avulsas (de ornamental curiosidade teórica, ou de preenchimento harmónico de supostas lacunas no sistema), mas porque a sua realidade pulsa do fundo prático do viver.

132 A passagem é, sem dúvida, sobejamente conhecida: «na realidade, e para o[s] materialista[s] prático[s], isto é, [para os] comunista[s], trata-se de revolucionar o mundo subsistente, de atacar e de transformar praticamente as coisas encontradas.» - «sich in Wirklichkeit und für den praktischen Materialisten, d. h. Kommunisten, darum handelt, die bestehende Welt $\mathrm{zu}$ revolutionieren, die vorgefundnen Dinge praktisch anzugreifen und zu verändern.», MARX - ENGELS, Die deutsche Ideologie, I, A, 2; MEW, vol. 3, p. 42.

Seria todavia precipitada leviandade interpretar este posicionamento como redundando numa simples expressão metafísica de um «praticismo» furioso que evacua e proscreve a compreensão. A crítica (teórica) não substitui decerto a transformação material, mas, dialecticamente, esta de modo algum dispensa aquela. A «base mundana» (weltliche Grundlage) das coisas e dos processos «tem, por isso, em si própria, tanto que ser entendida na sua contradição, como praticamente revolucionada.» - «muß also in sich selbst sowohl in ihrem Widerspruch verstanden als praktisch revolutioniert werden.», MARX, Thesen über Feuerbach, 4; MEW, vol. 3 , p. 6 . 
Como Marx, em confronto aberto com as cogitações do «Único», certeiramente lembrava, «o indivíduo real» (das wirkliche Individuum), que Stirner magnificava na figura estilizada do «Nada» (Nichts), acaba afinal por se constituir como «um algo muito vário» (ein sehr mannifaltiges Etwas) ${ }^{133}$, que - que na, pela, e com a sua complexidade não impenetrável - tem a sua génese material, e um contexto determinado de implantação histórica e de funcionamento, que lhe proporcionam e balizam o campo deveniente de uma afirmação e de uma intervenção livre.

Liberdade - não é ausência de determinações. É autodeterminação no enfrentamento e na modelação de condições - herdadas, circundantes, e em processo de transformação sempre vibráteis.

Não há individualidade caída do Céu, para amarar, pronta e equipada, nas águas acolhedoras de uma «consciência» que lhe passa a servir de paramento. Como Marx e Engels lembravam, numa formulação com um forte endereço ontológico (e não apenas gnosiológico, ou cultural): «A consciência [das Bewußtsein] nunca pode ser algo de outro senão o ser consciente [das bewußte Sein], e o ser [Sein] dos seres humanos é o seu processo real de vida [ihr wirklicher Lebensprozeß].» ${ }^{134}$.

Não há individualidade fora, ao lado ou acima, de um elemento materialmente fundado, e dinâmico - de relacionalidade. É desse, e nesse, horizonte de relacionamentos que a «ipseidade» (sem dúvida, «singular» e "própria») se dá, firma, e manifesta - trabalha e se trabalha, adquirindo densidade e expressando-se em obra ${ }^{135}$.

133 Cf. MARX - ENGELS, Die deutsche Ideologie, III, 1, Altes Testament: Der Mensch, 4, A; MEW, vol. 3, p. 133.

É também neste sentido que, mais adiante, no quadro de uma demarcação do «comunismo» relativamente à pregação de uma «Moral» de contornos filantrópico-sentimentais abstractos, se esclarece que «os comunistas não querem, portanto, de modo nenhum, [...] por amor ao [Homem] "universal", ao Homem sacrificado, suprimir [aufheben] o "homem privado" [Privatmensch]» - «die Kommunisten wollen also keineswegs [...] den "Privatmenschen" dem "allgemeinen", dem aufopfernden Menschen zuliebe aufheben», MARX - ENGELS, Die deutsche Ideologie, III, 1, Neues Testament: "Ich", 2; MEW, vol. 3, p. 229.

134 «Das Bewußtsein kann nie etwas Andres sein als das bewußte Sein, und das Sein der Menschen ist ihr wirlicher Lebensprozeß.», MARX - ENGELS, Die deutsche Ideologie, I, A; MEW, vol. 3, p. 26.

135 «A primeira pressuposição de toda a história humana é naturalmente a existência de indivíduos humanos vivos.» - «Die erste Voraussetzung aller Menschengeschichte ist natürlich die Existenz lebendiger menschlicher Individuen.», MARX - ENGELS, Die deutsche Ideologie, I, A; MEW, vol. 3, p. 20 -, isto é, ocupados na produção do seu próprio viver, modelando e gerando as próprias condições em que este se desenvolve.

É porque os indivíduos não se dão etereamente «como puros eus» (als reine Ichs), e por esta constitutiva unidade dialéctica de relacionamentos com o mundo 
É num «mundo» (que não é «nosso»), e juntamente (por vezes, em contradição) com outros (de que não somos «proprietários»), que, de um modo não forçosamente «alienado» (por potentes que se insinuem as induções de alienação), vamos construindo - nos «grandes actos» que a memória regista em crónica, como nos quotidianos gestos que passam despercebidos - aquela mediação histórica concreta do ser que (singular e colectivamente, segundo diferentes arrumações da grupalidade) nos mergulha na aventurosa viagem que é viver.

Sem uma demanda de fundada compreensão ontológica do acontecer, na sua intrínseca contraditoriedade deveniente, podem certamente alguns espíritos argutos comprazer-se «em inventar novas frases para a interpretação do mundo subsistente» ${ }^{136}$; mas não é fatal que à lógica «cega», ou «selvagem», do modo instalado e hegemónico de produção e de reprodução do estabelecido nos tenhamos, por demissão (não apenas «política» ou «ética», mas ontológica), de encomendar.

Estas tarefas de reconfiguração e de transformação são decerto - nos seus traços determinantes - comunitárias, e decorrem em condições que não por inteiro se controlam; em caso algum, porém, evacuam ou dispensam - numa individualidade desperta, e empenhada no seu «fazer» (e no seu «fazer-se») - o envolvimento de um momento ético subjectivo, até porque «na actividade revolucionária, o transformar-se [das Sich-Verändern] coincide com o transformar [Verändern] das circunstâncias.» ${ }^{137}$.

No entanto, é sempre conveniente irmos estando precavidos - sobremaneira, os que ao pensar filosófico nos dedicamos - contra um escorregadio perigo que, a cada passo, espreita: «a transformação de colisões práticas (isto é, de colisões dos indivíduos com as suas condições práticas de vida [praktische Lebensbedingungen]) em colisões ideiais [ideelle Kollisionen] (isto é, em colisões desses indivíduos com representações que eles se fazem ou que eles se metem na cabeça)» ${ }^{138}$.

e com outros, que «a história de um indivíduo singular», que não é apagada ou dissolvida neste (ou por este) enfoque, «de modo algum é de desprender da história dos indivíduos precedentes e contemporâneos» - «die Geschichte eines einzelnen Individuums keineswegs von der Geschichte der vorhergegangenen und gleichzeitigen Individuen loszureißen ist», MARX - ENGELS, Die deutsche Ideologie, III, 1, Neues Testament: "Ich", 6; MEW, vol. 3, p. 423.

136 «neue Phrasen zur Interpretation der bestehenden Welt zu erfinden», MARX ENGELS, Die deutsche Ideologie, III, 1, Neues Testament: "Ich", 5, III, 2; MEW, vol. 3, p. 379.

137 «In der revolutionären Tätigkeit fällt das Sich-Verändern mit dem Verändern der Umstände zusammen.», MARX - ENGELS, Die deutsche Ideologie, III, 1, 6, B; MEW, vol. 3, p. 195.

138 «die Verwandlung praktischer Kollisionen, d. h. Kollisionen der Individuen mit 
É que este resvalamento, em regra, a mais não conduz, por abstinência ou debilidade da prática, do que à «canonização do mundo» (Kanonisation der Welt) tal como ele está - ou seja, talvez, como ele se encontra numa outra figura remoçada de aquilo que, em 1842, Stirner designava por «barbárie diplomática» (diplomatische Barbarei) ${ }^{139}$.

Muito obrigado, pela vossa paciência única.

ihren praktischen Lebensbedingungen, in ideelle Kollisionen, d. h. in Kollisionen dieser Individuen mit Vorstellungen, die sie sich machen oder sich in den Kopf setzen», MARX - ENGELS, Die deutsche Ideologie, III, 1, Neues Testament: "Ich", 3; MEW, vol. 3, p. 268.

139 Cf. STIRNER, Über B. Bauers Posaune des jüngsten Gerichts (1842); KS, p. 17. 